

\title{
Boom Towns and Ghost Countries: \\ Geography, Agglomeration, and Population Mobility
}

\author{
Lant Pritchett \\ Kennedy School of Government \\ and \\ Center for Global Development \\ CGD Working Paper \#36 \\ February 18, 2004
}




\section{Boom Towns and Ghost Countries: Geography, Agglomeration, and Population Mobility ${ }^{1}$}

Is Zambia a ghost country? People moved to Zambia, and to a particular region of Zambia, in part because you could dig a hole in the ground and extract something of value - copper ore ${ }^{2}$. Technological changes in the world economy appear to have permanently reduced the profitability of copper mining. There are currently around 10 million people within the imaginary lines called the borders of the nation-state of Zambia. Imagine that Zambians were free to move anywhere in the world how many would still be within the current borders of Zambia? If a potential ghost country is defined as a country that has far more people that the "constrained desired" amount, then my conjecture is that Zambia is a potential ghost—but because people are not allowed to move across borders Zambia is not an actual ghost with declining population but is a zombie country (not an actual ghost, but the living dead) — trapped into low and falling (and/or stagnant) income and wages by a lack of population mobility.

The post World War II has produced a historically unique economic experiment of more nation-states and globalization without labor mobility. In 1940 there were only 65 independent countries while almost twice that many - 125 countries — have been created in the last 60 years $^{3}$. Figure 1 shows the three waves of state creation-the first

\footnotetext{
${ }^{1}$ I would like to thank the LIEP and Development Lunch groups at Harvard for helpful comments, in particular Dani Rodrik for the idea of migration as an issue, Ricardo Hausmann for the suggesting figure 6 and Mark Rosenzweig and Robert Lawrence for pushing on theory and interpretation. Hannah Pritchett produced the data and figures on county population movements. Eliana Carranza assisted in the final stages.

${ }^{2}$ I choose the example of Zambia of the example of copper and because I grew up near the world's largest open pit copper mine, the Bingham mine about an hour outside of Salt Lake City Utah. Since the price of copper has fallen the mine has changed ownership three times and the town just near the mine has been in continuous decline.

${ }^{3}$ Other methods and sources give different numbers, but with the same direction. Alesina, Spolare and Wacziarg (2000) report 69 in 1920, 89 in 1950 and 192 in 1995.
} 
wave of de-colonized states in South and East Asia following WWII, the second wave of states, principally in Africa, and finally the new states created from the dissolution of the Soviet Union. These new states obviously varied enormously in size (both territory and population), resources, location, and income levels.

\section{Figure 1: The number of sovereign states has tripled in the last 60 years} (Number of new states per year, by region)

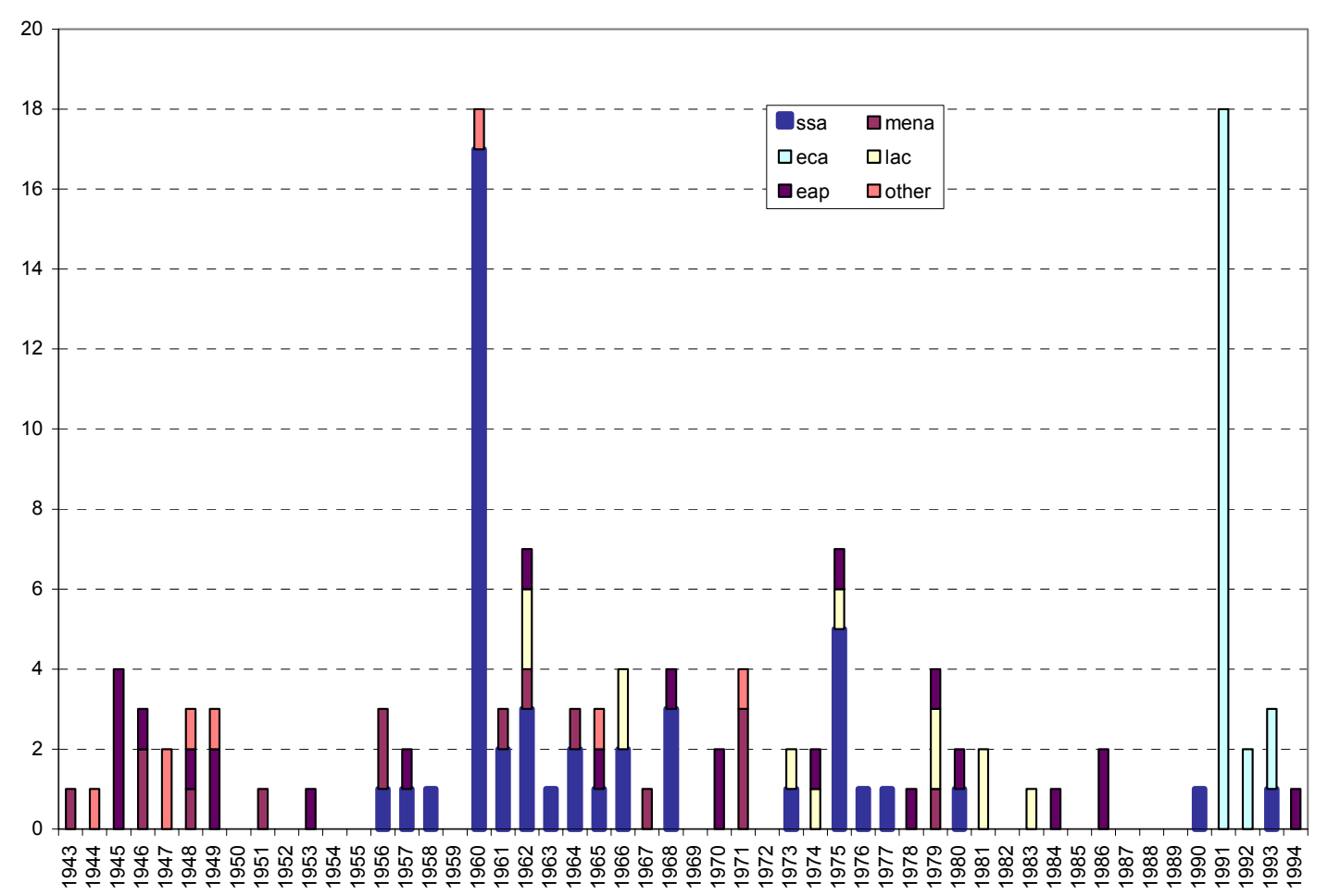

Each of these nation-states is sovereign within its own boundaries - and can determine their own economic policies, laws, regulations, political systems and who can cross their borders. The post-war international system encouraged economic transactions across borders by regulating the means of payment (IMF), providing a framework for negotiating reductions in trade barriers (GATT/WTO), and providing for capital flows (World Bank), first directly by lending and more recently by encouraging financial liberalization. But, unlike the first era of globalization from 1870-1914 which was an 
“age of mass migration" (Hatton and Williamson 1998) ${ }^{4}$ in the post-WWII international system each sovereign nation-state is allowed to limit all movement of persons across its borders at its own discretion. Moreover, there is no powerful international organization or mechanism encouraging nation-states to adopt more "liberal" policies for labor mobility.

Theory alone can not predict the outcome of (a) the "proliferation of sovereigns" (Braun, Hausmann, and Pritchett 2002) and (b) “everything but labor” globalization. Two of the "workhorse" models of growth and trade implied that if two regions had fully integrated markets for all goods and for capital and common economic policies, the movement of persons was not "necessary" to achieve convergence in output per capita" and/or the equalization of factor prices wages ${ }^{6}$. The movement of capital or goods could, in certain simple models, with certain restrictive assumptions on parameters, act as a complete substitute for labor movements. But cross-national incomes per capita have not converged ${ }^{7}$ nor have factor prices.

\footnotetext{
${ }^{4}$ There were virtually open borders between Europe and areas of recent settlement (what O'Rourke and Williamson 2002) call the "Atlantic Economy" but there were also substantial "South-South" movements of population- e.g. the movement of ethnic Indians to Caribbean and Eastern Africa and the movement of Chinese around East Asia.

${ }^{5}$ This generated the obvious empirical anomaly that while the bare bones Solow model extended crossnationally appeared to predict absolute convergence the experience was of divergence in per capita incomes across all countries both historically (Pritchett 1997, Bourguignon and Morrison 2002) and in the post 1960 data (though not across all people in the world in the recent period in which India and China are growing fast). In addition the bare bones Solow model would predict counter-factually large interest rates during the process of convergence (King and Levine 1995) and would predict counter-factually large capital flows from rich countries to poor countries (Lucas 1988). It is far beyond the scope of this footnote to describe how the three proposed theoretical resolutions of these anomalies ("conditional convergence" within a Solow model augmented for human capital (Barro and Sala-i-Martin 1997, Mankiw Romer Weil 1992), "new growth" theories that predict divergence (Romer 1986, Lucas 1988), and the emphasis on "convergence clubs" (Ben-David 1994)) have fared empirically.

${ }^{6}$ While, as with nearly any general theorem in economics the formal conditions for the "factor price equalization theorem" were very stringent and "unrealistic" the forces implied by the theorem-that, compared to autarky the net factor supplies change with integration and hence should change relative prices make a great deal of sense.

${ }^{7}$ That is, while there plausibly has been a reduction in the global personal distribution of income (Sala-iMartin 2002) because the two largest nations India and China have done relatively, especially since a
} 
Suppose that a realistic feature of a mode of the an international/interregional economy are region specific "shocks" that produce, even after all accommodating changes in capital stocks and goods, large persistent changes in labor demand.

- If there are such shocks and population mobility is allowed and hence regional supply of labor is elastic in the long-run one should observe large variability in the growth rates of populations and relatively small variability in the interregional growth of real wages. I use three examples of regions that have completely integrated (or integrating) markets for goods, capital, and labor (states/provinces/prefectures within countries, counties within the USA, countries in the "age of mass migration") to show that there are substantial movements of population in the course of convergence of wages/incomes.

- If there are such shocks and population mobility is restricted and hence the regional supply of labor is inelastic then and one should observe small changes in population due to mobility and correspondingly large variability in the growth of wages (and incomes). Across countries there is relatively little mobility of populations and the growth rates of income and wages are enormously variable.

The consequence of a distribution of large region-specific changes in labor demand is that there will be regions which experience large, persistent, positive shocks to labor demand and become boom towns. But there are also geographic regions that will experience large, negative, persistent, shocks. Since "desired" population can fall much 2004) the dispersion of GDP per capita across nations, which are the relevant unit to 'policies', widened. 
faster then the actual population this will create situations in which the actual population will vastly exceed its new "desired" level.

- If the negative shock is large enough and population movements are allowed these regions will become ghosts.

- If the negative shock is large and other regions prevent labor mobility then potential ghost countries become unrealized ghosts or zombie countries (the living dead) as nothing, besides out-migration, can prevent an extended and permanent downward movement in wages.

\section{Framework}

To get to the phenomena of ghost countries I need to start with the question: "what is the desired population of a given geographic region and how much does that vary over time?" This, it turns out, is a very hard question to ask because it has been largely ignored in the economic literature, for both theoretical and practical reasons. Theoretically, the implication of the Solow model and nearly all of its extensions is that the question of the "desired populations" of countries never arose because: (a) with constant returns to scale the location of production is formally indeterminate ${ }^{8}$, (b) within these growth models there was no "land" or "resources" or specifically geographic features, (c) if capital was fully and rapidly mobile then any incipient differences in the marginal product of labor could be equalized by capital mobility, (d) if knowledge of the

\footnotetext{
${ }^{8}$ Basically, for technical reasons it is just much easier to deal with models in which the aggregate production function has constant returns to scale - as in all generations of the Solow model. But the literal implication of constant returns to scale is that the distribution of economic activity across space is indeterminate - not a question that can be answered within the formal apparatus of a growth model. Practically, this was not such a great loss since the first generation of growth theorists were interested in the source of persistent growth of output per head in the already developed economies and since nearly all of these countries are economically (and spatially) large and since their economies did not have a strong resource component simply ignoring the spatial allocation of economic activity was not crucial to those questions.
} 
"production function" diffused then differences in "technology" could be eliminated by moving "ideas" not people, and (e) the models were about the evolution of aggregates within a set of boundaries that were assumed fixed. Since population movements across countries have been tightly restricted during the entire period in which growth economics has been formalized and elaborated it has been a plausible assumption to "close" growth models with the assumption of zero labor mobility and even exogenous population growth ${ }^{9}$.

However, two recent strands of research: the economics of increasing returns to scale and agglomeration economies and the empirical literature on the determinants of growth, are putting geography and population mobility back on the map (so to speak).

Trade economists have re-introduced increasing returns to scale into models of international trade (Helpman and Krugman 1985) and from there into spatial economics $\left(\right.$ Krugman 1991) ${ }^{10}$. This combination has led to the use of the new formal apparatus for addressing fundamental questions like "what determines the number and location of cities?" (e.g. Fujita, Krugman, Venables 2000). A second element of this interest in agglomeration economies is the continued interest in regional economies and the rise and decline of populations of cities and regions within countries. Blanchard and Katz (1992) document state level movements in employment in the USA and demonstrate convergence in real wages but large, persistent, variability in population growth rates across states. Recent papers have examined the role of both productivity changes and

\footnotetext{
${ }^{9}$ Although fertility was made endogenous in some models (Barro-Becker, Galor and Weil).

${ }^{10}$ The "new growth" models a la Romer (1986) introduced the possibility of increasing returns to scale to some factors and hence re-introduced the possibility of agglomeration economies and scale economies. Many of the implications of the scale effects of the "first generation" of growth models were clearly counter-factual, the more recent vintage are at least arguably plausible, although (Jones 2003) points out the question of whether "scale effects" are "bug or a feature" or growth models is still open.
} 
demand changes in simultaneously determining population sizes and real estate prices (e.g. Glaeser and Gyourko, 2003).

The empirical literature estimating growth regressions has re-discovered ${ }^{11}$ the notion that there are connections between the geographic characteristics of countries and their economic performance. In particular the work of Sachs and Gallup (1998) emphasized spatial factors like tropical location and transport costs (proxied by being landlocked or having navigable rivers) on economic potential and economic growth. The work of Sachs and Warner (1995) introduced the notion of a "resource curse"- that countries richly endowed with natural resources had, on average, lower growth rates (Auty 1999). This work on resources has been followed by theoretical work on the causal linkages that explain these empirical regularities of geographic features on growth with a variety of causal paths working through "institutions" or "politics" or both". Moreover, authors reviewing the basic facts of economic growth are again emphasizing the important role of agglomeration economies in explaining the spatial distribution of output (Easterly and Levine 2002).

\section{I.A) A general set of equations for regional growth}

To discuss "growth" and regional population mobility—particularly of geographic shifts--one needs a framework within which output, factors, and labor are simultaneously determined. At a minimum this framework needs to specify a production function, the

\footnotetext{
${ }^{11}$ I emphasize "re-discovered" because, to be fair to the giants on whose shoulders we stand, it was never lost on any development economist that most poor countries were in the tropics and most rich countries were not, or that access to waterways for transport reduced transportation costs. My conjecture about the intellectual history whereby these facts disappeared is that, in their previous incarnation, these geographic facts were given racist and/or colonialism rationalizing explanations and hence the discrediting of the "explanations" discredited the "facts" - but that is conjecture.

${ }^{12}$ There is a huge and ongoing debate about the sources of these differences. Are they purely geographic (Sachs Warner) or are they the impact of some (perhaps long past) geographically based characteristic on "institutions" (e.g. Sokoloff Acemoglu, Johnson, Robinson) or are they the impact of resource endowments on current politics (Isham, Pritchett, and Woolcock, 2003).
} 
level and evolution of "productivity" and the evolution of accumulated factors and finally, how population is distributed.

Suppose there are $i=1, \ldots, N$ spatially distinct regions — which could be either geographically arbitrary units ${ }^{13}$ or political/administrative sub-units of countries (districts, counties, states, provinces, prefectures).

Output determination. Output at any point in time as a function of productivity and factors of production. I'll only assume that the production function is separable.

1) $y^{i}=A^{i} f\left(K^{i}, L^{i}\right)$

Productivity (A). I classify elements that effect the trajectory of the long-run equilibrium productivity of the $\mathrm{i}^{\text {th }}$ region under four headings: "geography" $\mathrm{G}$, the "policy" P, the "institutions" I, and the "technology" T where each capital letter represents both current and future values ${ }^{14}$.

2) $A^{i^{*}}=A\left(G^{i}, P^{i}, I^{i}, T^{i}\right)$

Growth models often assumed that A represented exclusively something like "technology"- a set of blueprints for "netputs"--and assumed that this technology was freely available or diffused rapidly across regions so that all regions (within or across countries) shared the same A. Later models have incorporated a role for policies or institutions in affecting A as well—what is a role for "geography" in productivity?

\footnotetext{
${ }^{13}$ For instance, the USA is divided for geological survey and cartographic purposes into "sections."

${ }^{14}$ That is, as a matter of description at this stage just think of these are multi-dimensional lists of all possible factors that affect productivity and that whatever it is that anyone proposes (from existence of malaria to rule of law to usable "blueprints" for production) be classified under one of those four headings.
} 
- The depletion of a location specific natural resource (mine, well, forest, soil quality, water table) that leads to a fall in the physical productivity of factors applied. Ghost towns around depleted mines are the classic examples ${ }^{15}$.

- A permanent fall in the relative price of a good produced with a location specific natural resource. The impact on coffee growing regions of the advent of new suppliers might be an (ongoing) classic example.

- Technologically induced changes increases in the physical productivity of given geographic region or resource. Changes in agriculture technology will differential change the productivities of lands endowed with the right combination of soil, water, and temperature. The differential impact of the Green Revolution strains of rice and wheat are the classic example.

Production function. A general production function could exhibit constant returns to scale in all factors, or increasing returns in some or all factors, or external economies, whatever. If the production function has constant returns to scale then it is impossible to discuss formally the spatial distribution of factors within any regional space that shares all other determinants of income in common. Increasing returns to scale or external economies of scale are able to "predict" the clustering of production into cities but the additional complications in modeling are considerable. The spatial equilibrium across regions depends on the balance of centrifugal and centripedal forces (Krugman 1998). Changes in the production function can make the forces stronger or weaker. The pressures for agglomeration are increased by either an increase in the returns to

\footnotetext{
${ }^{15}$ For me, the origin of some of this thinking is that I grew up in a town, Idaho City, which was once a thriving frontier town (the largest in Idaho territory) and has a population in 2000 of 458 people. Why? Simple. There used to be gold in the river nearby and now there isn't any commercially exploitable gold. 
scale/external economies or by shifts in the composition of demand towards the scale intensive activity.

Transport costs. The standard "iceberg" model of transport costs assumes that the production technology for transportation means that if one unit is shipped from the $\mathrm{i}^{\text {th }}$ region to the $\mathrm{j}^{\text {th }}$ region only $T^{i j}<1$ units arrive.

$$
\text { 3) } y^{j}=T C^{i, j} y^{i}
$$

Transport costs create a number of offsetting forces as if there were both intermediate goods and final goods. There are trade-offs between being near the intermediate inputs and being near the market for final demand. Krugman and Venables (1995) show that, starting from a very high level, transport costs can cause increases in agglomeration (population movement towards cities) and increased differences in wages across regions; while continued falls in transport costs can cause spatial spreading of production responding to wage differences.

Barriers to trade across regions can be modeled as increased transport costs (or vice versa) so that "globalizing" changes can come either through reductions in transport costs or policy changes or both.

Accumulated factors of production. The desired capital stock in a given region depends on the returns to investors that depend on the physical productivity of additional capital in that region (which depends on the general productivity, the production function and transport costs) and on the appropriability of those returns. In production functions with agglomeration effects the returns to any one investor depend on the investment decisions of all other investors and hence raise issues of multiple equilibrium. The appropriability of returns depends on policies (e.g. official tax rates) and institutions (e.g. 
legal and political risk). If we assume capital markets are integrated, there is a globally available safe return $\bar{r}$, then optimal capital stock in the $\mathrm{i}^{\text {th }}$ region $K^{i^{*}}$ equates the return in the region to the global return for the equilibrium labor force.

$$
\text { 4) } \bar{r}=\left(1-\tau\left(P^{i}, I^{i}\right)\right) * \frac{\partial\left[A\left(G^{i}, P^{i}, I^{i}, T^{i}\right) f\left(K^{i^{*}}, L^{i^{*}}\right)\right]}{\partial K}
$$

Given the long-run equilibrium capital stock to get to growth one needs to specify an equation of motion - the dynamics of the adjustment of the capital stock given its long-run value. I am agnostic about the specification - in particular because the usual linear dynamics imply symmetry to increases and decreases in the capital stock that is implausible for large deviations.

5) $\dot{k}=g_{K}\left(K_{t}^{i}-K^{i^{*}}, A S^{K}\right)$

\section{I.B) Allocation of population/labor across regions}

The above formulation of output allows a definition of a region's "constrained desired" population. That is, one can imagine the $k^{\text {th }}$ person living in region $i$ can move into region $j$ only by incurring some actual moving cost $C^{i, j, k}$. The regions differ in attractiveness due to their income but also a set of other factors that affect utility/wellbeing (e.g. language, culture, 'ethnicity', temperature/climate, congestion) for a person living in that region- $Z^{\mathrm{i}, \mathrm{k}}$.

Also, over and above potential income and other feature that determine utility, the de facto and de jure legal and administrative restrictions on population mobility create a set of individual and bilateral region specific set of "virtual taxes" $\tau^{i, j, k}$. I assume the virtual tax on remaining in the region of one's birth is zero. These are "virtual" taxes 
because they are expressed as the price equivalent of what might be binding quantity constraints - that is since borders are enforced using the compulsion of police/military power the virtual tax could be large enough to prevent all movement.

This "virtual tax" formulation of the constraints on population mobility can encompass a range of alternatives ${ }^{16}$. One case is "free population mobility" with zero virtual taxes across all pairs of regions and for all persons. In this case utilities are equalized across all regions (not necessarily per capita incomes, even in real terms, because of the "Z").

Another paradigm case is "full national mobility/zero international mobility." Lets assume that country $\mathrm{C}$ includes $J^{C}$ regions (and the "rest of world" is $J^{-C}$ ) and is represented as with zero internal virtual taxes within the country $\left(\tau^{i, j, k}=0, \forall i, j \in J^{C}\right)$. If person $k$ is born in the boundaries of $\mathrm{C}$, and a virtual tax is infinity (as it can be with coercion) $\tau^{i, j, k}=\infty, \forall j \in J^{-C}$ for all regions not in the country - both for people moving from $\mathrm{C}$ to other regions or from other regions to $\mathrm{C}-$, then the non-virtual tax inclusive utility is not being equalized across countries and hence negative geographic shocks can produce widening differences in wages/incomes/utility across regions.

Of course, between these two extremes of "full national/no international" and "full global" labor movement there are many possible variants. Some countries may not allow full internal mobility (e.g. China). In other places there may be full mobility across some countries and not others (e.g. the EU). Finally, even if labor mobility is banned or limited de jure, the de facto situation conditional on current and anticipated enforcement of labor laws creates a very different set of virtual taxes.

\footnotetext{
${ }^{16}$ This draws heavily on the Neary and Roberts (1980) formulation of "virtual prices" as a modeling technique for quantity constraints on allocations and trades. 
Finally, the virtual taxes on labor mobility can be person specific as immigration regimes of the $j^{\text {th }}$ region could allow "high skill" but not "low skill" immigration or "family unification" mobility, or whatever basis the legal regime wishes to recognize.

The constrained desired population of a region is simply the population of all individuals who prefer to live in region $i$ given the anticipated long-run equilibrium income of region $i$ with its fully adjusted stocks of capital and labor and the set of virtual taxes in all other regions ${ }^{17}$.

6) $L^{i^{*}}=\sum_{k=1}^{K(J)} I^{k}\left\{U^{k}\left(y^{i^{*}}, Z^{i, k}, t^{i, j, k}\right) \geq U^{k}\left(y^{j^{*}}, Z^{j, k}, C^{i, j, k}, \tau^{i, j, k}\right), \forall j \in \mathbf{J}\right\}$

The desired population is the population with zero virtual taxes.

Finally, the labor force/population needs an equation of motion for the adjustment of actual labor to the constrained desired level:

7) $i=g_{L}\left(L_{t}^{i}-L^{i^{*}}, A S^{L}\right)$

This raises the obvious problem that the population within a given region depends both on the "rate of natural increase" (the excess of births over deaths within the region) and on the mobility of persons across regions. While many researchers have made fertility and mortality behavior endogenous to economic growth and assumed no labor mobility - I am going to do the opposite and assume, for now, that the rate of natural increase is exogenous in order to focus on mobility.

\section{I.C) How much variability in output, how much variability in labor}

\footnotetext{
${ }^{17}$ An enormous problem with this approach is how exactly to make fertility endogenous. If we take $\mathrm{K}(\mathrm{J})$ as all people now alive then the "constrained desired" population holds population fixed-but over long periods one fertility is dependent on opportunities for mobility and anticipated income prospects.
} 
How important are spatially specific (geographic and/or agglomeration) factors in determining growth rates of incomes and populations across regions? The above framework leads to a set of equations that specify the growth rates of per capita income and the labor force as jointly endogenous variables that are potentially driven by a whole host of determinants — among which are at least two that are spatially specific: geographic specific elements of productivity and agglomeration economies in factor accumulation.

$$
\begin{aligned}
& \dot{y}_{t, t-n}^{i}=y\left(G, P, I, T, T C, f, Z, A S^{K, L}, \tau^{i,-i}\right) \\
& \dot{l}_{t, t-n}^{i}=l\left(G, P, I, T, T C, f, Z, A S^{K, L}, Z, \tau^{i,-i}\right)
\end{aligned}
$$

Each of the variables (e.g. G, P) represents an entire trajectory as observed growth rates over any given period $t-n$ to $t$ can be caused by changes in the past leading to adjustments, anticipated changes in the future or even steady state differences in trajectories that depend on levels.

Theory usually assumes away geographic factors for three good reasons - if one is modeling a large advanced industrial country like the USA, Japan or France. First, in a spatially large economy that encompasses a large number of distinct regions the likelihood of any one, or even a set of, geographic factors affecting aggregate growth is small. Second, for advanced economies the share of directly natural resource based industries (agriculture, mining, fisheries) is small. Third, fundamental geographic factors that affect levels and whose impact on output has not changed recently (e.g. climate) could be assumed away in modeling growth.

But none of these three are true in general of the non-OECD countries. First, dividing geographic space up into smaller and smaller units this increases the potential 
for geographic, policy, or institutionally induced variability in the income fundamentals (G,P,I,T). This is not to say that "small is bad"- as the "boom towns" like Hong Kong and Singapore are obviously very small. Second, the exports are often both natural resource based and concentrated in many non-OECD countries. Third, there are changes to spatial factors that strongly affect output.

Labor mobility is not important if desired populations do not change. Desired populations might not change (much) if either (a) the fundamentals don't change or (b) the mobility of other factors can compensate. The attractiveness of the regions might not change because there are no changes in the interaction of geography and economics that cause people for first want to be in one place and then not want to be there. So, labor mobility is not important for Antarctica because no substantial populations ever moved there-its attractiveness for human populations has not changed. But the classic counterexample is the exploitation of natural resources - first people do want to be there and then, when the extraction of the resource loses value people want to leave. The existence of "ghost towns" - places that were once booming and attracting migration which subsequently decline and even disappear — suggest that there is variability to desired populations.

But even if there are regional shocks there might not be large variations in desired population if the mobility of other factors can compensate. So, suppose a region attracts population because it relies on one type of economic activity and then some natural or economic shock makes that activity no longer viable. There is no longer any reason for people to be there as opposed to any other place — but they are there. One possibility is that new activities are created and resources (capital) flows to that place and people 
sustain roughly their same living standards but change their activities. Certainly, in the story of many of the major cities of the world the original reason for the cities location has long since ceased to be relevant (e.g. fortification, transport linkages) but the city continues to thrive.

But there are two other possibilities. One is that new resources do not flow and people leave. The other possibility is that the desired population falls, perhaps dramatically, but that people are not allowed to leave and hence all of the adjustment to the variability in the desired population of regions is forced onto real wages and living standards.

I do not have, at this stage, any particular compelling way of isolating the importance of spatial shocks, but I do have two empirical strategies, each of which has huge difficulties. The first strategy is to examine the variability of growth of income per person and of population across regions within countries. This is interesting because it is the equivalent of "complete integration"-regions of countries have similar (if not identical) "policies" and "institutions" and have access to the same "technologies" and there are no barriers to goods or capital movements. In these circumstances, if there are large population movements across regions and hence large variability of population, this is strongly suggestive of the importance of spatial factors that determine desired population. The problem is that changes in the desirability of location could be on the "demand" side—as people prefer living in warmer places, for instance.

The second strategy is to show that the variability of population growth is small across countries but that the variability of growth of income per head is enormous both across countries and within countries over time. This is consistent with large spatially 
specific shocks that cannot be accommodated by population movements and hence cause falls in income per head. The problem is that across countries there are so many other determinants of income that are not constant. There could be "policy" ghosts or "institutional" ghosts - and certainly a great deal of the variation in growth rates is not due to geographic or agglomeration.

Before moving to the empirical results I want to stress that my discussion on "desired" population of regions has nothing to with the usual "population pessimism" that rapidly growing populations are per se a problem or that rapid population growth is are a significant independent cause of slower growth in output per capita. In many ways this type of analysis gets it exactly backwards - it is not that populations are bad for output growth it is that slow output growth is bad for the living standards of populations. That is, the real "population crisis" is not when populations grow at $2 \%$--all of the successful East Asian countries began their rapid growth with high rates of population growth. The problem is not that population is rising towards the desired level— the problem is when desired population collapses to (or below) the actual population because of either exogenous shocks, technological changes, or bad governments (whether population continues to grow or not).

\section{How much change in population, how much change in income per capita?}

This section proceeds in three steps, mainly with graphs, followed by a summary table. First, in spatially large and populous countries with perfectly integrated markets for goods and capital and (roughly) equal institutions and policies the variability across regions of the growth rates of populations is as large, and often much larger, than the variability of the growth of income per person. Second, variability in the growth of 
income per head is enormously larger than either population growth rates, or particularly, than growth rates due to population mobility (the difference between actual population growth and the rate of natural increase) across countries in which populations cannot move freely. Third, we compare the variability of growth rates of population and income per person across countries to that across regions of countries. The within country variability of growth of income per person is much smaller than across countries while the variability of population growth rates is larger - and the mobility induced variability of populations enormously larger.

\section{II.A) Variability of growth rates of income per person and population within countries}

Barro and Sala-I-Martin (1997) have shown that regions within countries show a strong tendency for convergence (both absolutely and conditionally). I use the data from their book on income per head and population within regions of countries (which could be states/provinces/prefectures/regions) to show the absolute variability of the growth rates of the two series.

With no legal constraints to population mobility, workers/households will move —at least in part— in response to economic opportunities. Within regions of a fully integrated region or a larger unit, the variability in the rate of growth of output per worker should be very small—and there should be powerful forces towards convergence in real incomes. But this could or could not involve population movements, as a change in the desired population of a region is the combination of shocks and that shock not being fully accommodated by movements in other factors such as capital or by trade. Theory alone provides no unambiguous prediction about the magnitude of inter-regional population movements. 
Seeing is believing, a picture is worth a thousand words, etc. But one problem with the typical comparison of growth rates of income per capita and population is that nearly all standard software packages that display graphs scale the axes independently so it is impossible to visually infer the respective variances. So here I do two things which are non-standard. One, in all of the figures below I scale the axes so that the range on the vertical (growth of output per capita) and horizontal (growth of population) axes are equal. Second, I display percentile boxes which show the vertical/horizontal distance between the 10th and $90^{\text {th }}$ percentiles ${ }^{18}$.

Figures 2 and 3 show three features of the growth of income per person and the growth of population for the continental states of the USA and prefectures of Japan. First, the dispersion of growth rates of population is larger than the dispersion of per capita income growth. In the USA the $10 / 90$ range for population is 2 ppa (.6 to 2.6) versus only $1.2 \mathrm{ppa}$ (1.3 to 2.5 ) for income growth. In Japan the 10/90 range is $1.9 \mathrm{ppa}$ (.3 to 1.6 ) for population and only $1 \mathrm{ppa}$ (4.8 to 5.8 ) for income. Second, the absolute variability in population growth across these regions within countries is about the same as variability in population growth rates across all non-OECD countries - and substantially larger than the net population growth rates $(10 / 90$ ratio of $.8 \mathrm{ppa})$. Third, the variability of growth rates of income per head is spectacularly larger across countries than across regions within countries-10/90 differences of 4.6 ppa across non-OECD countries and only around 1 ppa for the regions of USA and Japan.

The similar figures for all of the other countries with data in the Barro and Sala-iMartin (1997) are in appendix 1. These typically show less within region variability-

\footnotetext{
${ }^{18}$ These boxes are orthogonal to the axes as I am not so interested in displaying the covariances as I am interested in comparing the differing variability in the two series.

Draft: Comments Welcome 
but in all of them the variability in population growth across regions is larger than variability in growth of income per head. 
Figure 2: Per annum growth of income per person and population across states of the United States.

(States of the USA, 1900-1990, 10/90 boxes)

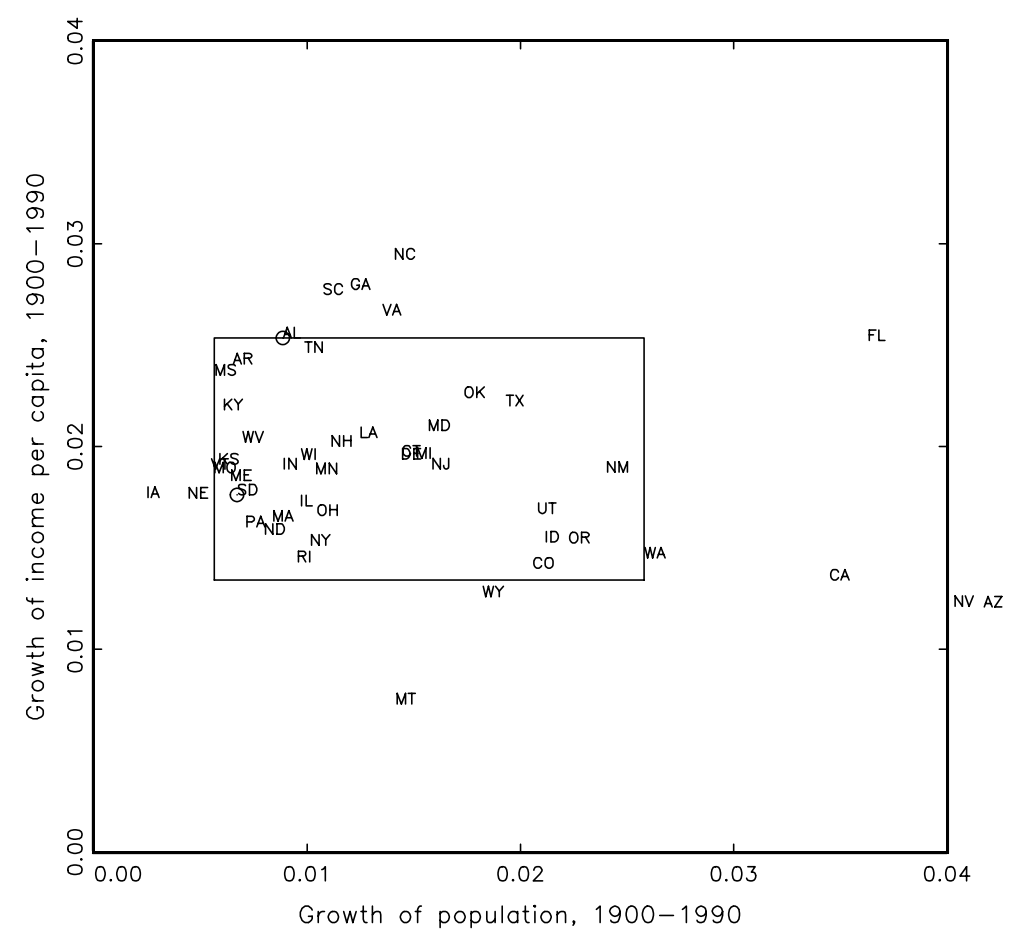

Figure 3: Per annum growth of income per person and population across Japan

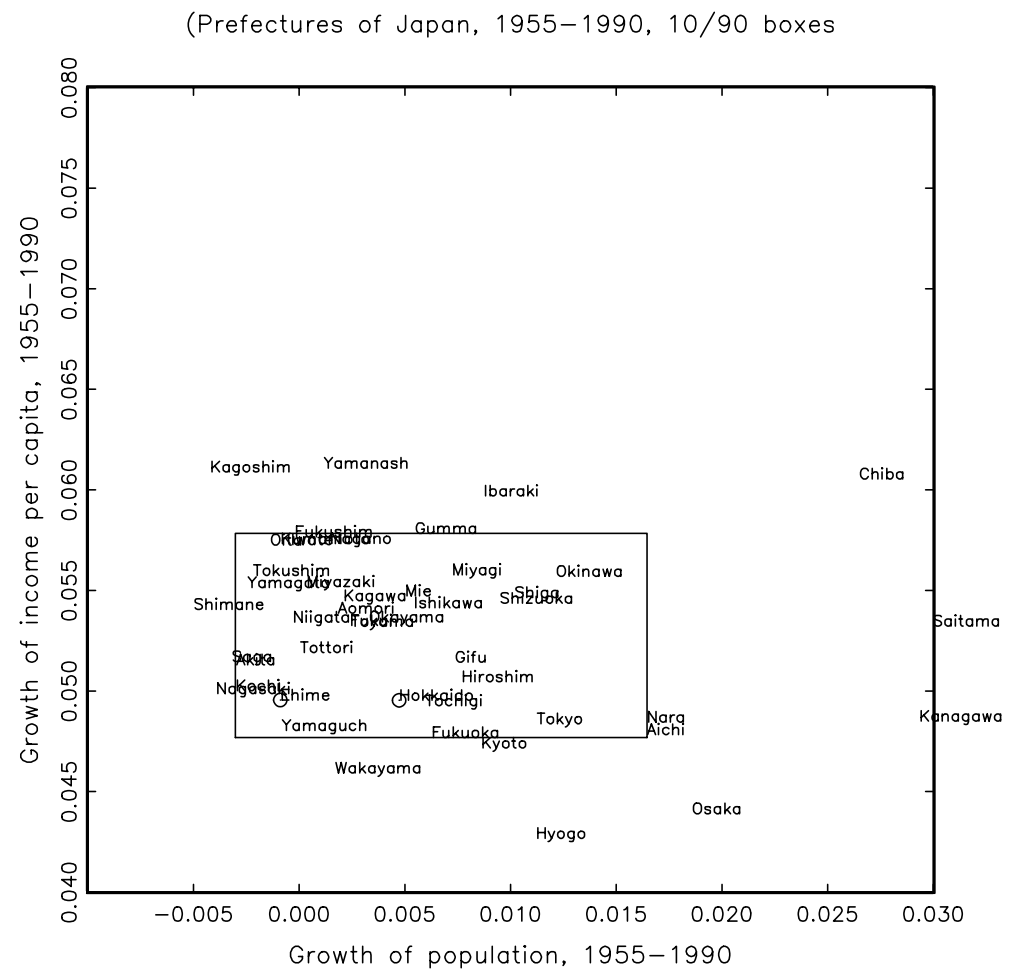

Draft: Comments Welcome 


\section{II.B) Variability of growth rates of income per person and population across countries}

With many sovereign states and constrained labor mobility shocks to desired population should create wide variability across countries in output per person growth rates and little variability of population. That is of course, exactly what one sees in Figure 4. Per annum growth rates of GDP per capita are calculated as a least squares growth rate over the longest period available for each country in the Penn World Table 6.0 data for all countries with at least 20 years of data. Per annum growth rates of population are calculated for the same period. The range of growth rates is more than 9 percentage points - from over 6 ppa for Singapore and Taiwan to less than negative 2 for Zaire, Niger, Angola. In contrast the range of population growth rates is from about 3.5 ppa (excluding the very high rates reported for Jordan) to about $.5 \mathrm{ppa}$. 
Figure 4: Per annum growth of GDP per capita and

\section{population}

(Non-OECD countries, 1950-2000, 10/90 boxes)

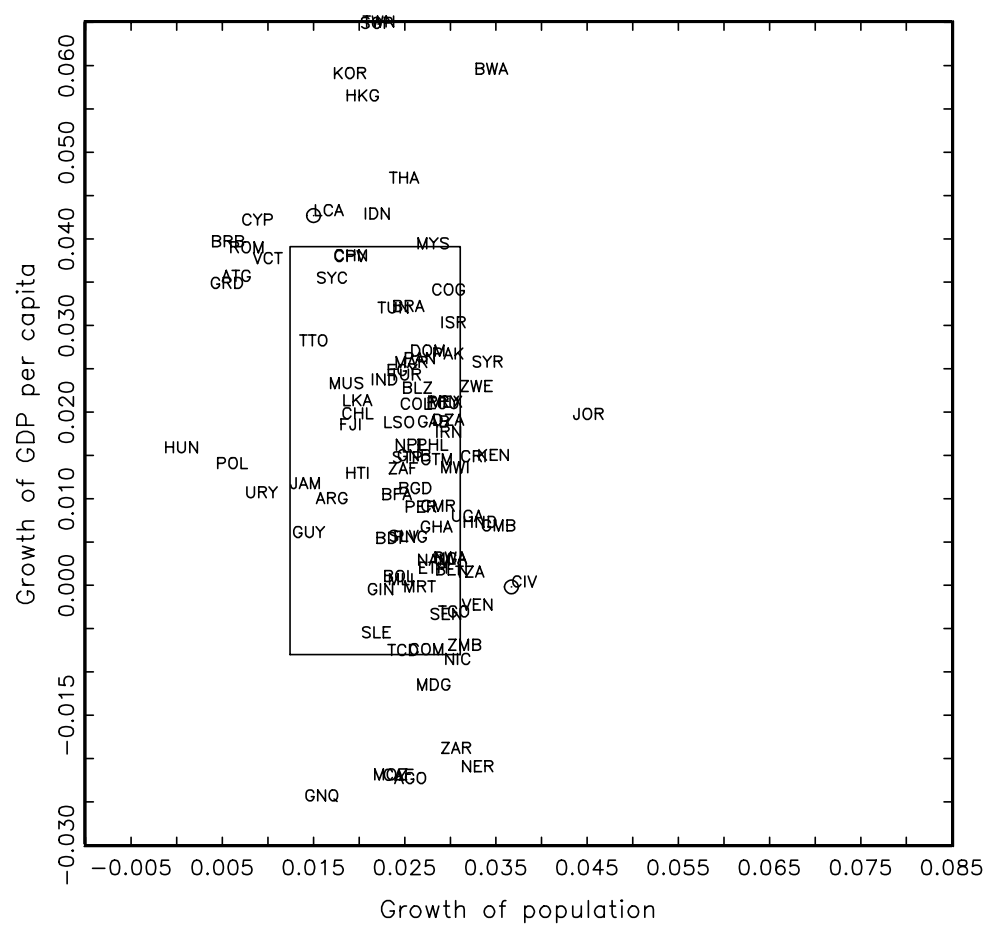

Of course population growth alone overstates the extent to which population

mobility has played a role as much of the cross-national variation is due to very different rates of natural increase. To compare cross-national to inter-regional growth of population — where nearly all of the differences are due to mobility—I use the rate of population growth less the rate of natural increase (crude birth rates less crude death rates) as a proxy. But this almost certainly understates actual population mobility as it is very difficult to get estimates of population that do not, to a greater or lesser extent, depend on extrapolations based on the rate of natural increase. The compromise is to report both raw population growth rates and population growth net of natural increase (which I will call "net population growth" in a simple but awkward use of 'net'). 
As can be seen in figure 5 the variability of growth of GDP per capita is enormously larger than the variability of net population growth rates. The standard deviation of Y/P growth is 1.9 while the standard deviation of net population growth is .4 -almost five times smaller. The $10 / 90$ percentile range for growth rates is 4.6 ppa (from -.8 to 3.8 ) while the range for net population growth is only .8 ppa (-.5 to .3 ) almost six times smaller. 
Figure 5: Per annum growth of GDP per capita and net population (population less rate of natural increase)

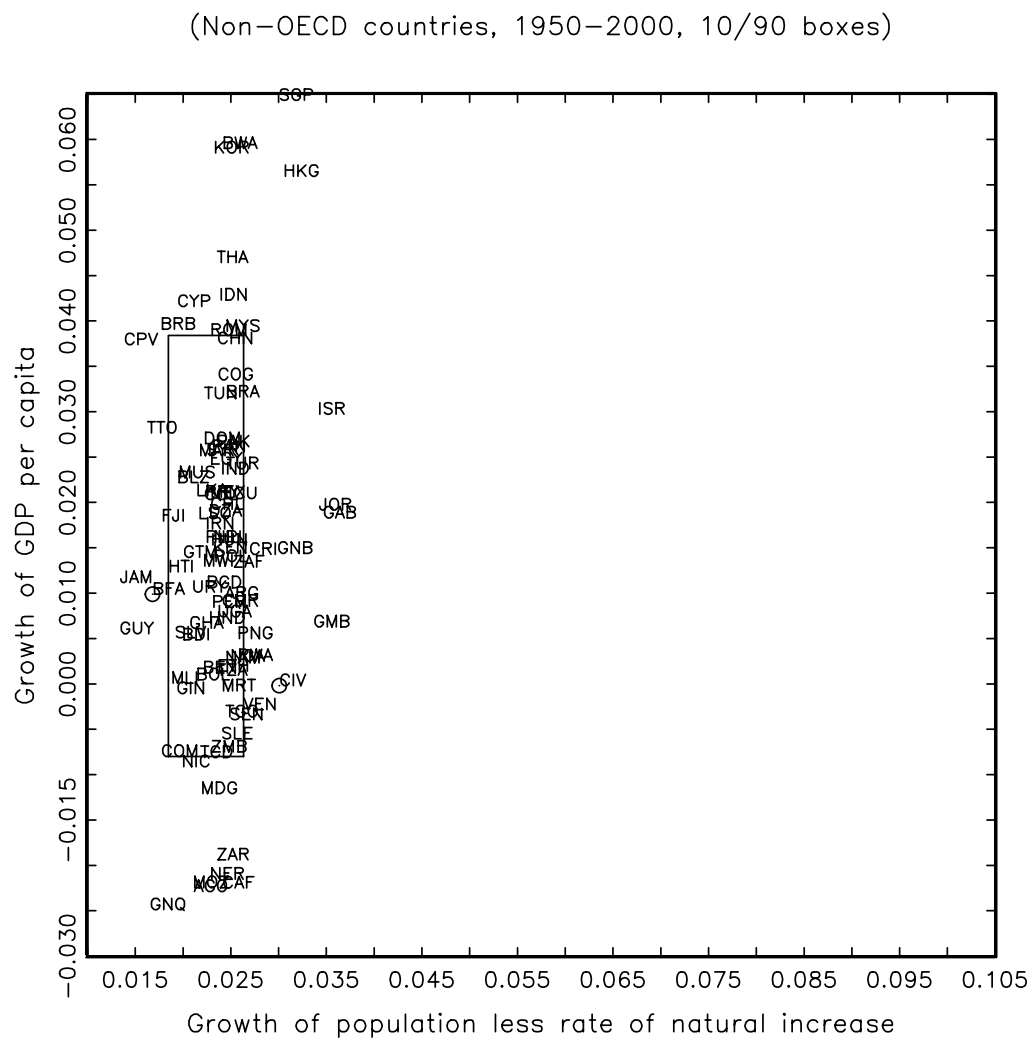

\section{II.C) Comparing across country versus within country variability of growth rates}

The variance in growth rates of populations across regions within countries with no barriers to mobility indicates how much desired populations vary across geographic regions - even when goods and capital markets are perfectly integrated and "policies and institutions" are (more or less) the same. The question is whether that variability is "large" both in an absolute sense and in particular whether this is large relative to the observed variability in populations across countries. Moreover, if the variability of population across countries for which there are formal barriers to mobility is low, and if the variability of desired populations is large, one would expect the adjustment to happen through larger variability in output per person. 
The first two columns of table 1 show that the variability of populations within countries is large - often twice as large as the variability of income per head. Strikingly, the standard deviation of the growth rates of population across non-OECD countries is .78--than the population growth variability within regions of the USA (.92), Canada (.78), Japan (.78) or Spain (.80) and only a little more than twice that of most European countries. To some extent these comparisons vastly understate the difference as nearly all of the variance in population growth rates across non-OECD countries is due to differences in rates of natural increase, as these countries are at very different points in the demographic transition, while nearly all of the within country regional variability in population growth is due to mobility. The variability of population net of the rate of natural increase is very much smaller across countries that within regions of a country.

The final two columns show whether variability in the desired populations of a given geographic region are accommodated by population flows versus changes in growth rates. The ratio of the variability of population to income per person growth is between 4 and 14 times as high for regions within countries as across countries. This is consistent with a large degree of variability in geographic specific productivity which is no eliminated by goods or capital movements and which results in population movements where allowed and in large variability in income per head where people are not allowed to move. 
Table 1: Ratios of the dispersion of growth rates of population and GDP/income per person across regions within countries and across countries

\begin{tabular}{|l|l|l|l|l|}
\hline & & \multicolumn{2}{|l|}{} & \multicolumn{2}{l|}{$\begin{array}{l}\text { Ratio of ratio of std. dev. for regions } \\
\text { within country to ratio of std. dev. Across }\end{array}$} \\
$\begin{array}{l}\text { Country/set of } \\
\text { countries }\end{array}$ & $\begin{array}{l}\text { Ratio } \\
\text { non-OECD countries }\end{array}$ \\
\hline $\begin{array}{l}\sigma_{\hat{P}} \\
\sigma_{\frac{Y}{P}}\end{array}$ & $\frac{\left|\hat{P}_{p 10}-\hat{P}_{p 90}\right|}{\left|\frac{\hat{Y}}{P}{ }_{p 10}-\frac{\hat{Y}}{P} p 90\right|}$ & $\begin{array}{l}\text { Population growth } \\
\text { in non-OECD } \\
\text { countries net of rate } \\
\text { of natural increase }\end{array}$ & $\begin{array}{l}\text { Population } \\
\text { growth }\end{array}$ \\
\hline $\begin{array}{l}\text { Non-OECD } \\
\text { (population) }\end{array}$ & 0.41 & 0.28 & - & - \\
\hline USA & 2.02 & 1.67 & - & - \\
\hline Canada & 2.37 & 2.56 & 9.58 & 5.95 \\
\hline Japan & 1.92 & 1.90 & 14.69 & 9.13 \\
\hline UK & 1.14 & 1.29 & 10.93 & 6.79 \\
\hline France & 1.02 & 0.83 & 7.39 & 4.59 \\
\hline Spain & 1.20 & 1.69 & 4.79 & 2.98 \\
\hline Germany & 0.80 & 0.73 & 9.73 & 6.04 \\
\hline Italy & 0.82 & 0.78 & 4.18 & 2.60 \\
\hline
\end{tabular}

Source: Author's calculations.

Figures $6 a, b$ and $7 \mathrm{a}, \mathrm{b}$ illustrate the same point as the table by showing the $10 / 90$ boxes for growth of population and income per person on the same scale for regions within countries and across non-OECD countries. 
Figures 6 a,b: Comparing variability of growth rates of output per capita and population within regions of countries (Japan, Canada, USA) versus across nonOECD countries

(Boxes at 90 th/10th percentiles of each variable)

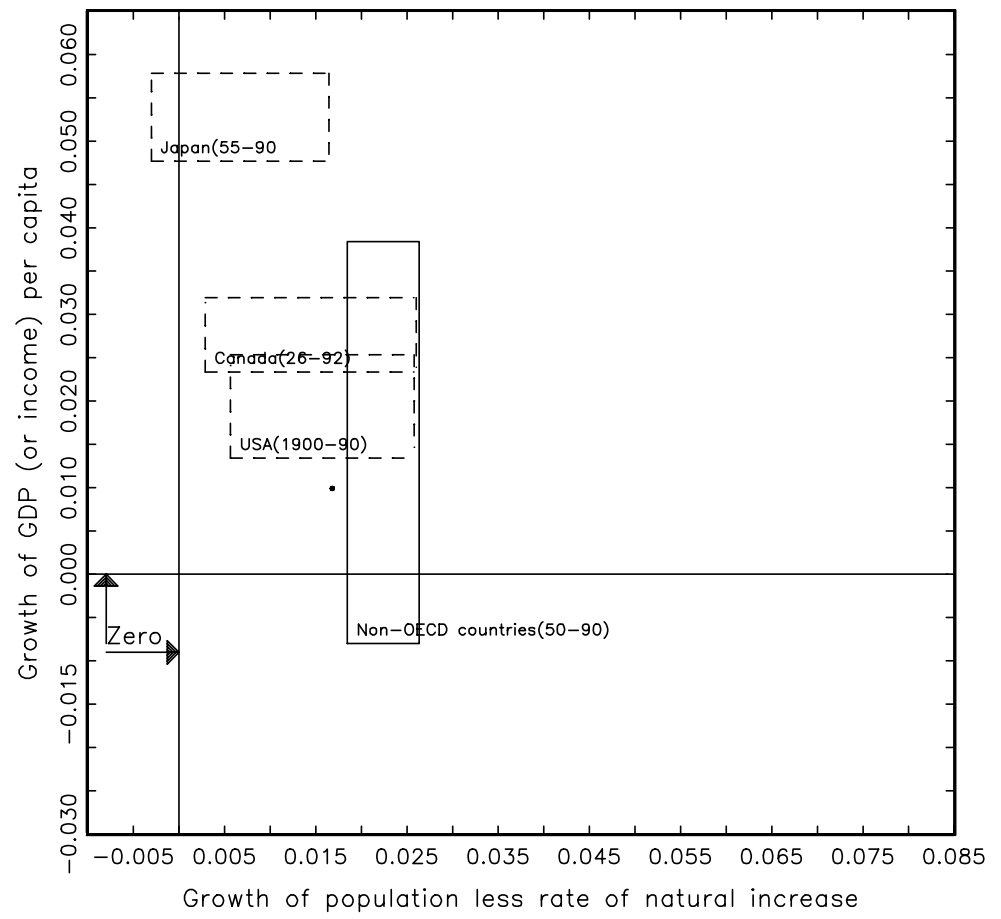

(Boxes at 90th/10th percentiles of each variable)

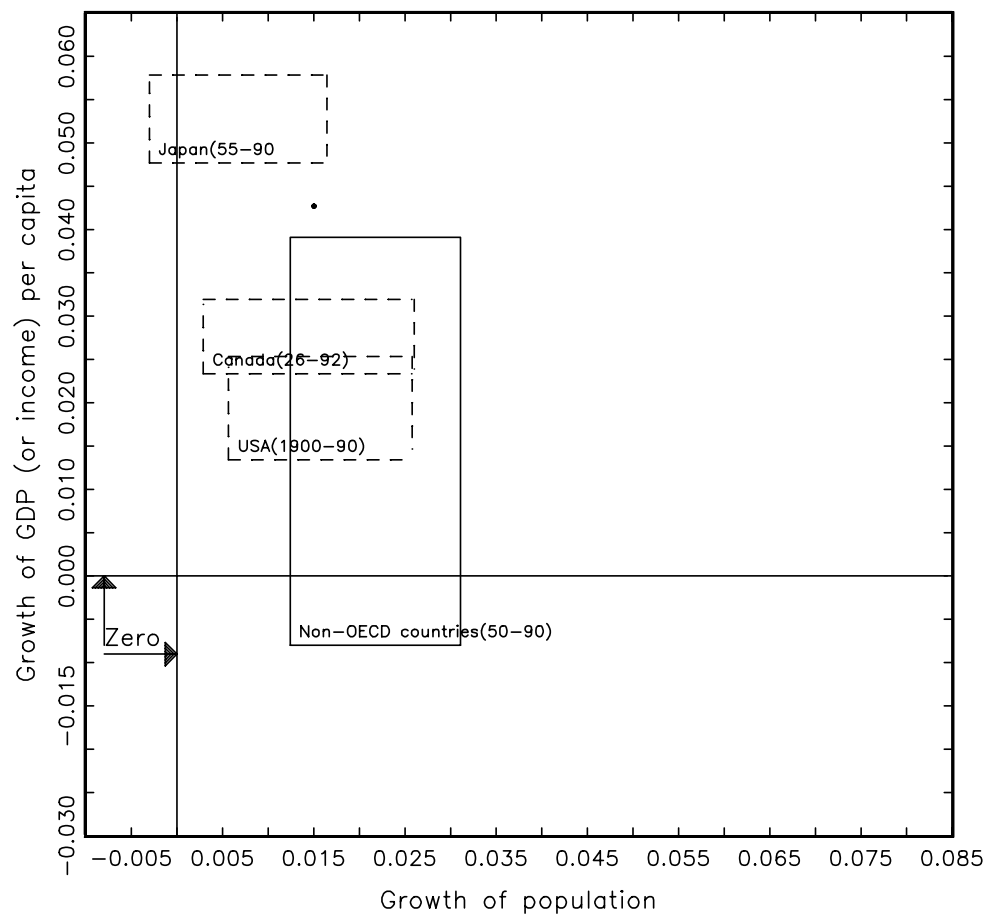

Draft: Comments Welcome 
Figures 7a,b: Comparing variability of growth rates of output per capita and population of regions of European countries (Spain, Italy, France, Germany, UK) versus non-OECD countries

(Boxes at 90th/10th percentiles of each variable)

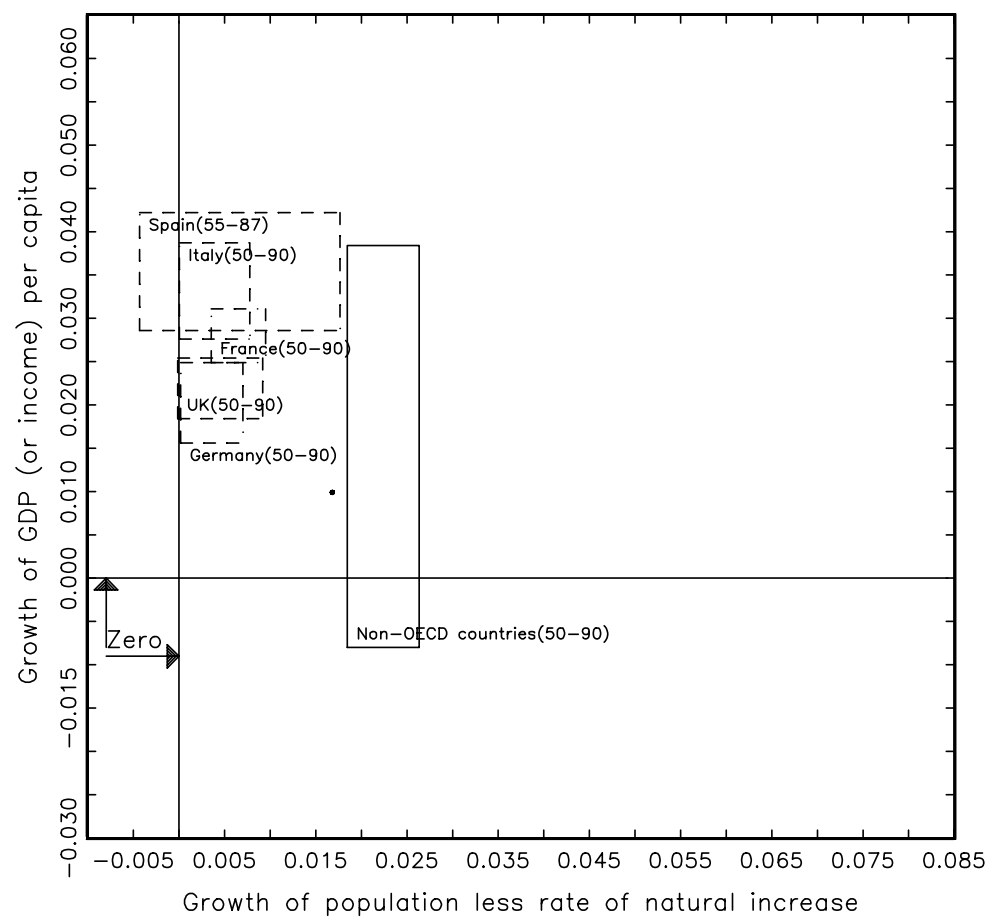

(Boxes at 90th/10th percentiles of each variable)

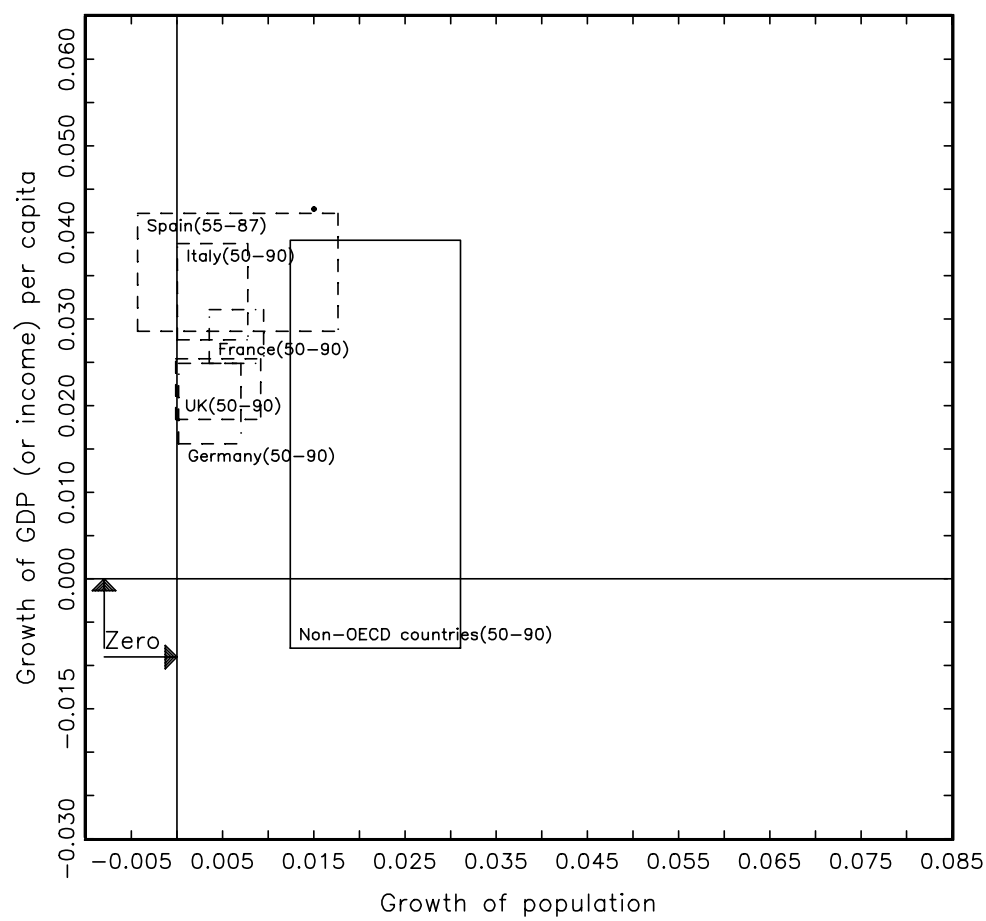

Draft: Comments Welcome 
These results are sufficiently striking that I want to emphasize they are not a trivial consequence of the obvious fact that people can move within regions and cannot move across national borders. There are many ways in which population mobility is allowed and yet not produce the above results. First, it is possible that geographic specific shocks to desired population are small. Using the within country inter-regional results reduces the impact of location specific policy, institution, or non-geographic technological shocks on desired populations. Second, it is possible that geographic specific shocks to income do not result in changes in the desired population as movements of goods or capital mitigate shocks. The finding that with unrestricted mobility there is convergence in incomes is not surprising. The finding that the differences in population growth across spatially large regions within a (reasonably) homogenous policy and institutional environment in a fully integrated economy are absolutely and relatively large is a non-trivial empirical finding.

\section{Ghost regions of the United States}

The previous section shows large differences in population growth across states of the USA. State level results perhaps understate the degree of spatial population mobility by smoothing over large areas — some of which increased while other decreased. Using data across the roughly 3,000 counties in the USA illustrates the enormous degree of spatial variation in desired populations. At the county level there are enormous changes in populations. While population in the United States overall has doubled since 1930 there are counties that have been essentially depopulated over the sixty years from 1930 to 1990 . Slope county North Dakota has seen its population fall from 4,150 to only 907 , Smith county Kansas from 13,545 to only 5078, Huerfano county Colorado from 17,062 
to only 6,009 and McDowell county West Virginia from 90,479 to only 35,233. In contrast, there are of course counties with explosive growth in population.

These population reductions are not simply isolated cases. I assemble collections of counties with the largest percent reduction in population from 1930 to 1990 of various sizes. The 612 counties with the most rapid population reduction — that in 1930 added up to 10 percent of the US population (around 12 million people) — lost 40 percent of their 1930 population and are only 30 percent as large as they would have been had they not experienced out-migration. The land area covered by these counties is the size of Bolivia. The 902 counties that contained 20 percent of the US population in 1930 (24 million people) lost 27 percent of their population over the next 60 years and are only 36 percent of the counter-factual of no out-migration. The spatial area covered by these 902 counties is larger than all but about 10 countries in the world. 
Table 2: Changes in populations of agglomerations of counties in the United States.

\begin{tabular}{|c|c|c|c|c|c|c|}
\hline $\begin{array}{l}\text { Agglomeration } \\
\text { of highest } \\
\text { percent } \\
\text { reduction in } \\
\text { population } \\
\text { that add up } \\
\text { to... in } 1930\end{array}$ & $\begin{array}{l}\text { Number of } \\
\text { counties } \\
\text { (out of } 3065)\end{array}$ & $\begin{array}{l}\text { Population } \\
1930 \\
(\cdot 000 s)\end{array}$ & $\begin{array}{l}\text { Percent } \\
\text { change } \\
1930- \\
1990\end{array}$ & $\begin{array}{l}\text { Current } \\
\text { population } \\
\text { relative to } \\
\text { rate of } \\
\text { natural } \\
\text { increase } \\
\text { counter- } \\
\text { factual }\end{array}$ & $\begin{array}{l}\text { Total area } \\
\text { (square } \\
\text { miles) }\end{array}$ & $\begin{array}{l}\text { Number of } \\
\text { countries } \\
\text { smaller in } \\
\text { land area }\end{array}$ \\
\hline $\begin{array}{l}1 \quad \text { Million } \\
\text { population }\end{array}$ & 84 & $1,015.1$ & -64.0 & $17.8 \%$ & 89111 & $\begin{array}{l}118 \\
\text { (Uganda, } \\
\text { Syria) } \\
\end{array}$ \\
\hline $\begin{array}{l}5 \quad \text { Million } \\
\text { population }\end{array}$ & 321 & $5,006.4$ & -52.2 & $23.6 \%$ & 309358 & $\begin{array}{l}160 \\
\text { (Turkey) }\end{array}$ \\
\hline $\begin{array}{l}10 \text { percent } \\
\text { of US } \\
\text { population }\end{array}$ & 612 & $12,140.2$ & -39.3 & $30.0 \%$ & 551345 & $\begin{array}{l}176 \\
\text { (Bolivia, } \\
\text { Mali) }\end{array}$ \\
\hline $\begin{array}{l}20 \text { percent } \\
\text { of US } \\
\text { population }\end{array}$ & 902 & $24,916.6$ & -27.5 & $35.9 \%$ & 774539 & $\begin{array}{l}181 \\
\text { (Mexico, } \\
\text { Indonesia) } \\
\end{array}$ \\
\hline
\end{tabular}

Source: Author's calculations based on county population data.

Of course, adding up counties sorted by their percentage reduction maximizes the fall and is not directly analogous to countries as these counties are not all together. A second exercise is to assemble counties which may cut across state boundaries but which are contiguous and that are a shape such that it is at least conceivable that, had history been different, a plausibly shaped state (or country) could have been formed with these boundaries. That is, while we deliberately gerrymandered the areas to include population losing counties we did not simply "cut out" cities or make dramatic detours to include this or exclude that county. Gerrymandering in this way I assemble five regions of the USA which I name-Texaklahoma (Northwest Texas and Oklahoma), Heartland (parts of Iowa, Missouri, Kansas Nebraska), Deep South (parts of Arkansas, Mississippi, 
Alabama), Coal Pennsylvania, and Great Plains North (parts of Kansas and South Dakota).

Even with the constraint of contiguity one can assemble spatially large territories that have seen substantial population decline. The Great Plains North is a territory larger than Great Britain and its population has declined 28 percent from 1930 to 1990 and is only a bit more than a third the population than had population growth been at the rate of natural increase. The Texalohoma region is bigger than Bangladesh and is only 31 percent the size it would have been in the absence of out-migration. We use a few counties in the coal producing region of Pennsylvania to illustrate that not all of these declines are explained by the decline of rural and agricultural populations- but natural resource shocks also play a role. 
Table 3: Population change in regions (contiguous collections of counties cutting across state borders) of the United States

\begin{tabular}{|c|c|c|c|c|c|c|}
\hline $\begin{array}{l}\text { Region of } \\
\text { the United } \\
\text { States } \\
\text { (contiguous } \\
\text { counties) }\end{array}$ & $\begin{array}{l}\text { Population } \\
1930 \\
\left({ }^{6} 000 s\right)\end{array}$ & $\begin{array}{l}\text { Percent } \\
\text { change in } \\
\text { population } \\
1930-1990\end{array}$ & $\begin{array}{l}\text { Ratio of } \\
\text { current } \\
\text { population } \\
\text { to counter } \\
\text { factual at } \\
\text { rate of } \\
\text { natural } \\
\text { increase }\end{array}$ & $\begin{array}{l}\text { Area } \\
\text { (square } \\
\text { miles) }\end{array}$ & $\begin{array}{l}\text { Number of } \\
\text { countries } \\
\text { (of 192) } \\
\text { with } \\
\text { smaller } \\
\text { area } \\
\text { (with } \\
\text { examples) }\end{array}$ & $\begin{array}{l}\text { Ratio of } \\
\text { area per } \\
\text { capita } \\
\text { income to } \\
\text { national } \\
\text { average }\end{array}$ \\
\hline Texlahoma & 835.8 & -36.8 & 0.31 & 58403 & $\begin{array}{l}117192 \\
\text { (Nicaragua, } \\
\text { Bangladesh) }\end{array}$ & $92.2 \%$ \\
\hline Heartland & 1482.6 & -34.0 & 0.33 & 59708 & $117 / 192$ & $85.2 \%$ \\
\hline Deep South & 1558.2 & -27.9 & 0.36 & 36284 & $\begin{array}{l}\text { 96/192 } \\
\text { (Jordan, } \\
\text { Austria, Sri } \\
\text { Lanka) }\end{array}$ & $62.6 \%$ \\
\hline $\begin{array}{l}\text { Pennsylvania } \\
\text { Coal }\end{array}$ & 1182.9 & -27.9 & 0.36 & 2972 & $\begin{array}{l}43 / 192 \\
\text { (Trinidad } \\
\text { and Tobago, } \\
\text { Mauritius) }\end{array}$ & $84.5 \%$ \\
\hline $\begin{array}{l}\text { Great Plains } \\
\text { North }\end{array}$ & 1068.0 & -27.7 & 0.36 & 100920 & $\begin{array}{l}\text { 128/ } 192 \\
\text { (Great } \\
\text { Britain, } \\
\text { Ghana, } \\
\text { Ecuador) }\end{array}$ & $85.4 \%$ \\
\hline Nation & 123202.6 & $101.9 \%$ & & 3536278 & & $100.0 \%$ \\
\hline
\end{tabular}

Source: Author's calculations with county data. 
Figure 8: Regions of the USA have seen enormous declines in population over a long time scale...

(Dark grey-lost more than 10,000, medium grey-lost 5-10,000, light grey lost 0-5,000, whitegained $0-10,000$, striped — gained more than 10,000)

Figure 8a: Changes in county populations in the "Heartland" region of the United States (selected counties of Iowa, Missouri, Nebraska, and Kansas)

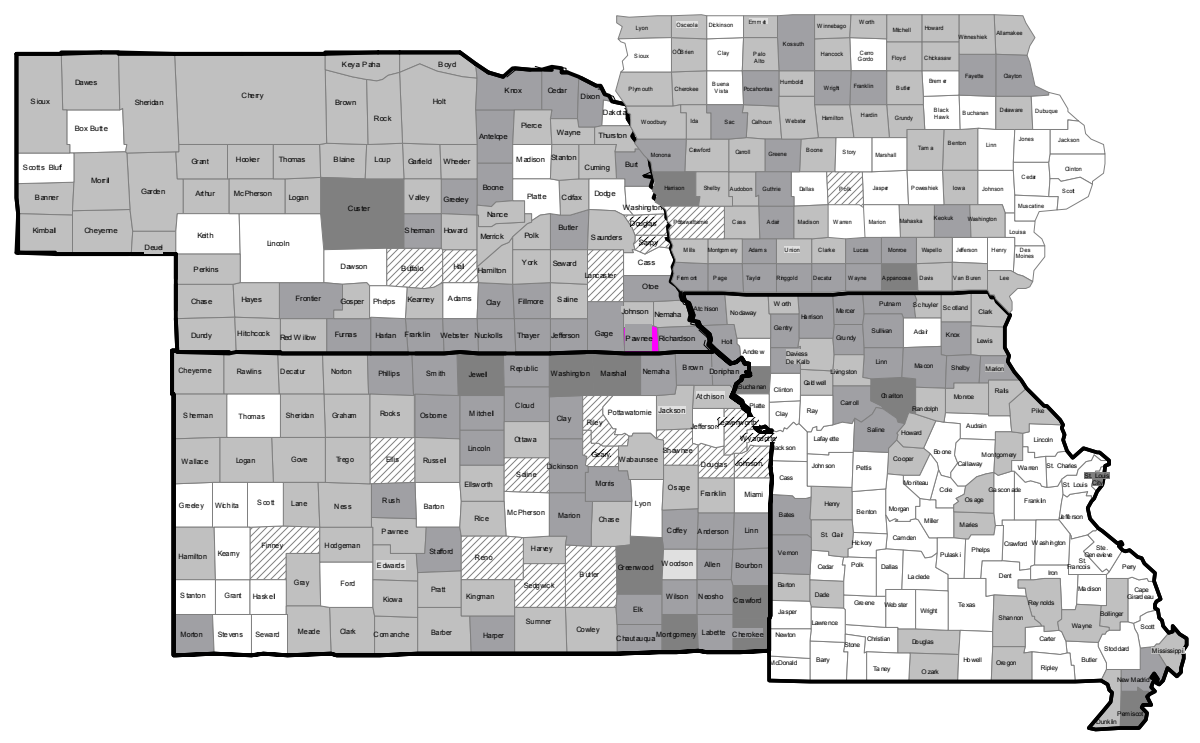

Figure 8b: Changes in county populations in the "Deep South" region of the United States (selected counties of Arkansas, Mississippi, and Alabama)

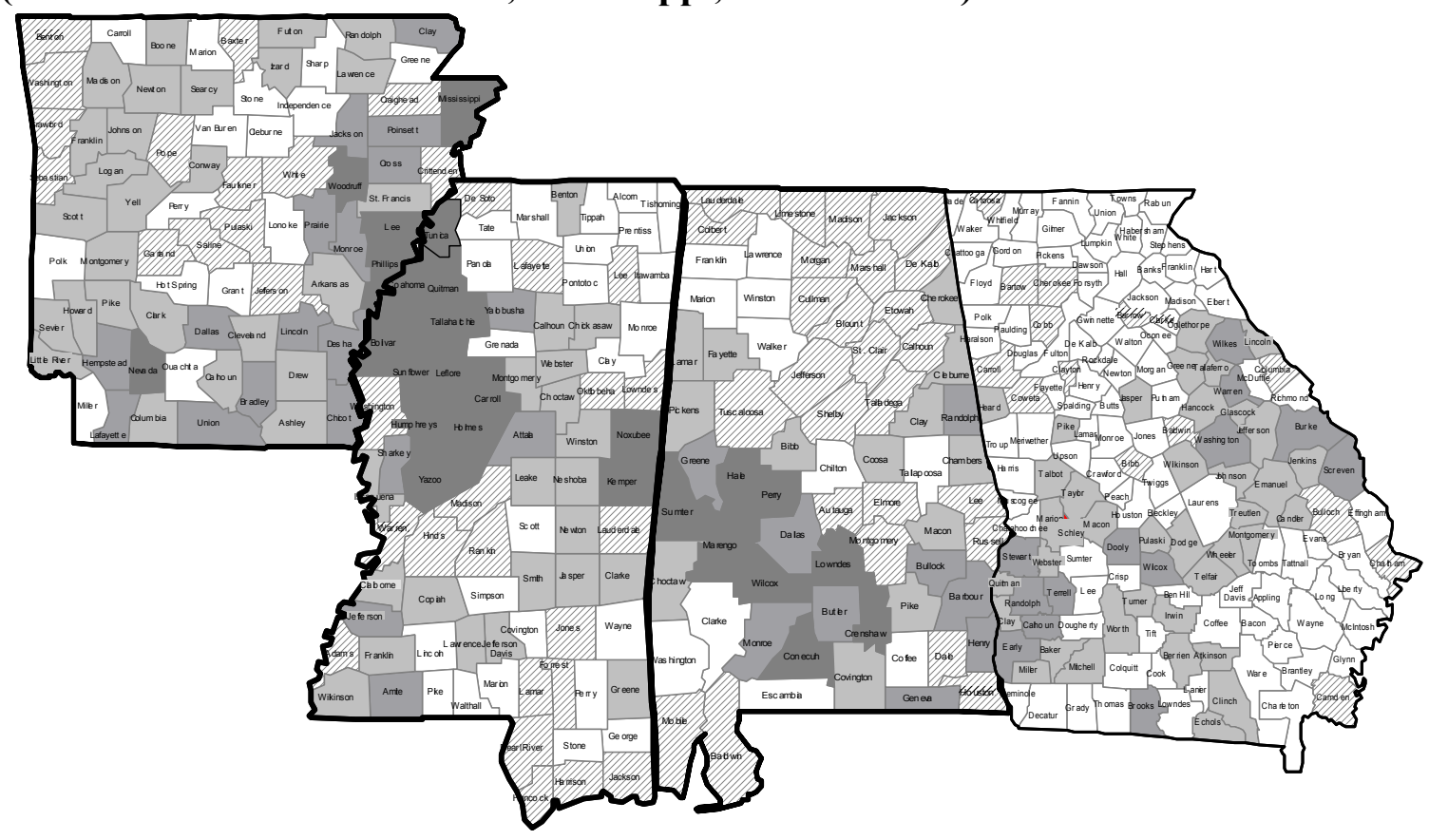

Draft: Comments Welcome 
Figure 8c: The "Pennsylvania Coal" region (selected counties of eastern Pennsylvania)

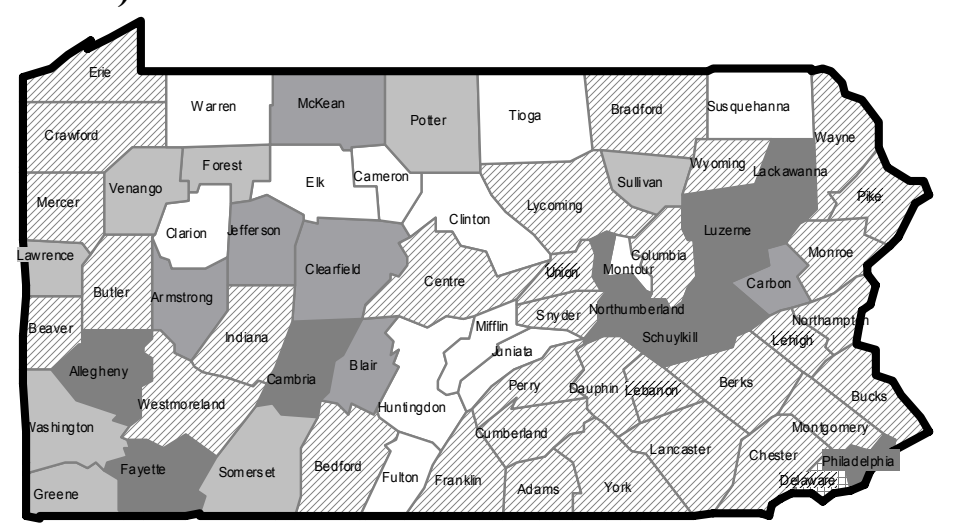

Figure 8d: County population changes in the "Great Plains North" region (selected counties of Nebraska and South Dakota)

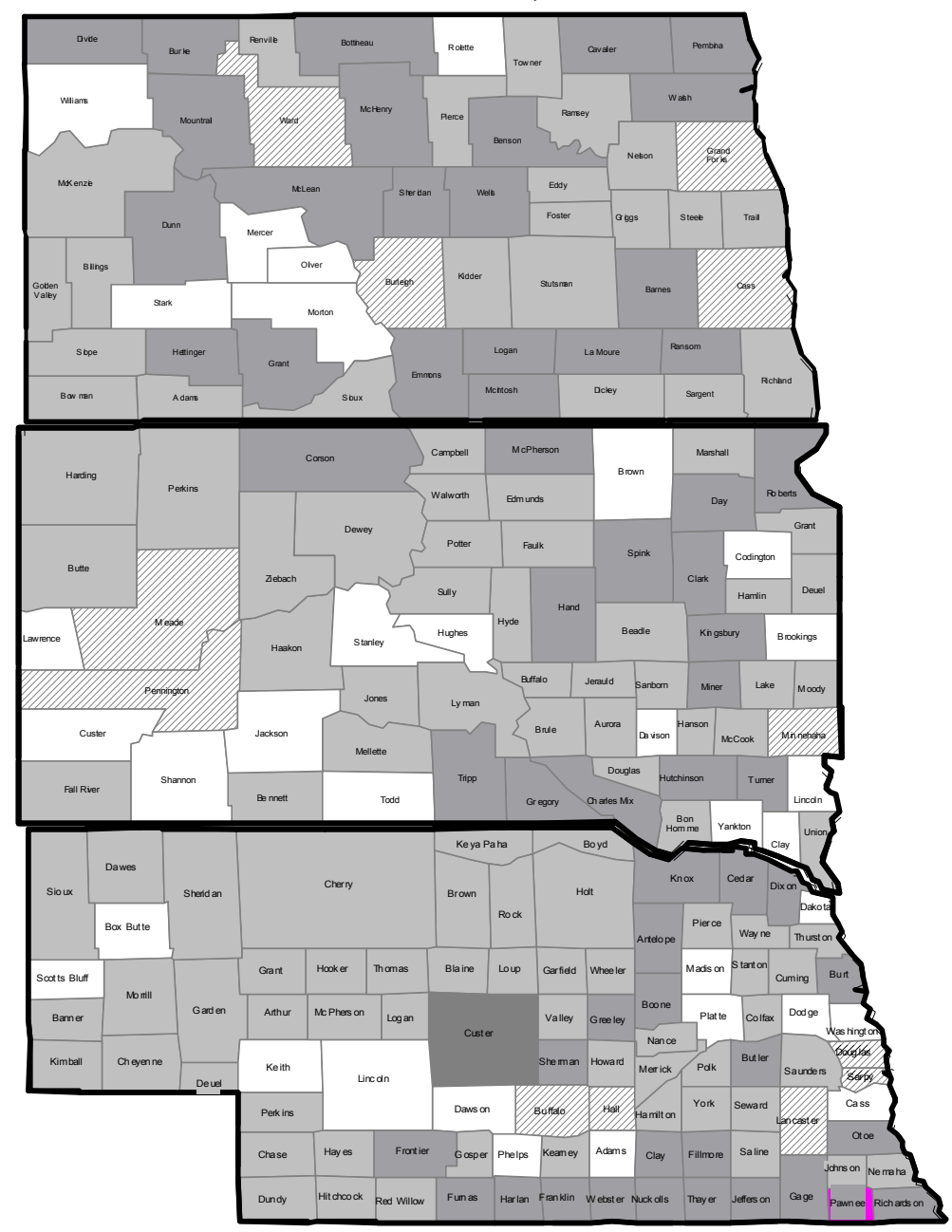


Regions within the USA can be seen as a thought experiment of what would happen in a fully "globalized" world—geographic units linked with fully integrated markets for land, capital, goods and labor. In such a world one can expect that incomes would converge in levels. With the exception of the Deep South, incomes of the population losing regions are more than 85 percent of the national average - so these regions are poorer than the national average_-but not dramatically so.

But one can ask - even with fully integrated markets with goods and capital and (roughly) equivalent policies and institutions how much variability is there in "desired populations" within regions? The answer: "lots." While it may be the case that population movements were less than they would have been because capital flowed to these regions and goods were mobile it is still the case that the population shifts within the United States are huge. In particular, they are vastly larger than the population shifts one sees across the often equally arbitrary boundaries of countries in the world today.

To a large extent this is a consequence of the well known phenomena of "urbanization" as everyone knows that the USA population went from rural to urban over this period. Glaeser and Kohlhase (2003) show a number of factors associated with the rise and decline of county population - e.g. having resource based industries was "bad" having sophisticated services was "good." My point is that it is logically possible that, as "urbanization" proceeds and populations agglomerate into cities, there are areas of geographic space which do not contain a single "city" in equilibrium. "Boom towns" attract enormous inflows of population. A "ghost country" might not contain, in a full mobility equilibrium, even a single city. 


\section{Accommodating shocks with population movements: Ireland}

The nineteenth century was an "age of mass migration" (Hatton and Williamson 1998) as many of the "areas of recent settlement" had open borders with respect to immigrant (at least of certain ethnic/national origin). It was also an era of rapidly reductions in transport costs and moves towards freer trade in goods, open capital markets (and massive movements in capital) — the first era of globalization. Hence this period is an interesting example of the question: "how we would expect geographic shocks to be accommodated in a globalizing world?"

The story of Ireland is an obvious, and dramatic, case in point. The introduction of the potato into Ireland has been a large positive shock-as it was a much cheaper source of calories per unit land and was well adapted to the climate. This technological innovation allowed population to grow without reducing output per worker-and population in 1841 was 2.5 times that of 1754 . However, given the dependence of the Irish economy on the potato, the onset of the potato blight in the 1840 s was an enormous negative shock. After the initial terrible period of the famine the economy in fact did reasonably well by the standard measures - real unskilled wages relative to the UK never fell. The available aggregate figures show that GDP per capita in 1870 was more than 40 percent higher than in 1820 .

The obvious mechanism of adjustment was out-migration, which was substantial. Since we are used to see trends with steady exponential increases in population the counter-example of Ireland is stunning. Peak recorded population of Ireland was over eight million $(8,175,000)$ but by 1901 population had fallen to only about four and a half million $(4,459,000)$ - a net loss of 3.7 million people. And this against of course rates of 
natural increase that would have led to increasing population. This contraction radically changed the relative size of countries - Canada in 1871 was less than half Ireland's peak while by 1991 Canada was five times as large. Ireland was larger than Belgium in 1871 and only 60 percent as large by 1911 . Even today with Ireland booming economically Irish population is only 70 percent of its peak-the same level as 200 years ago.

Figure 9: During the period of accommodating the shock of the potato famine and its aftermath in Ireland real wages never fell—but population fell to almost half its previous peak

(Index of population, real unskilled urban wages, and GDP per capita, 1870-1)

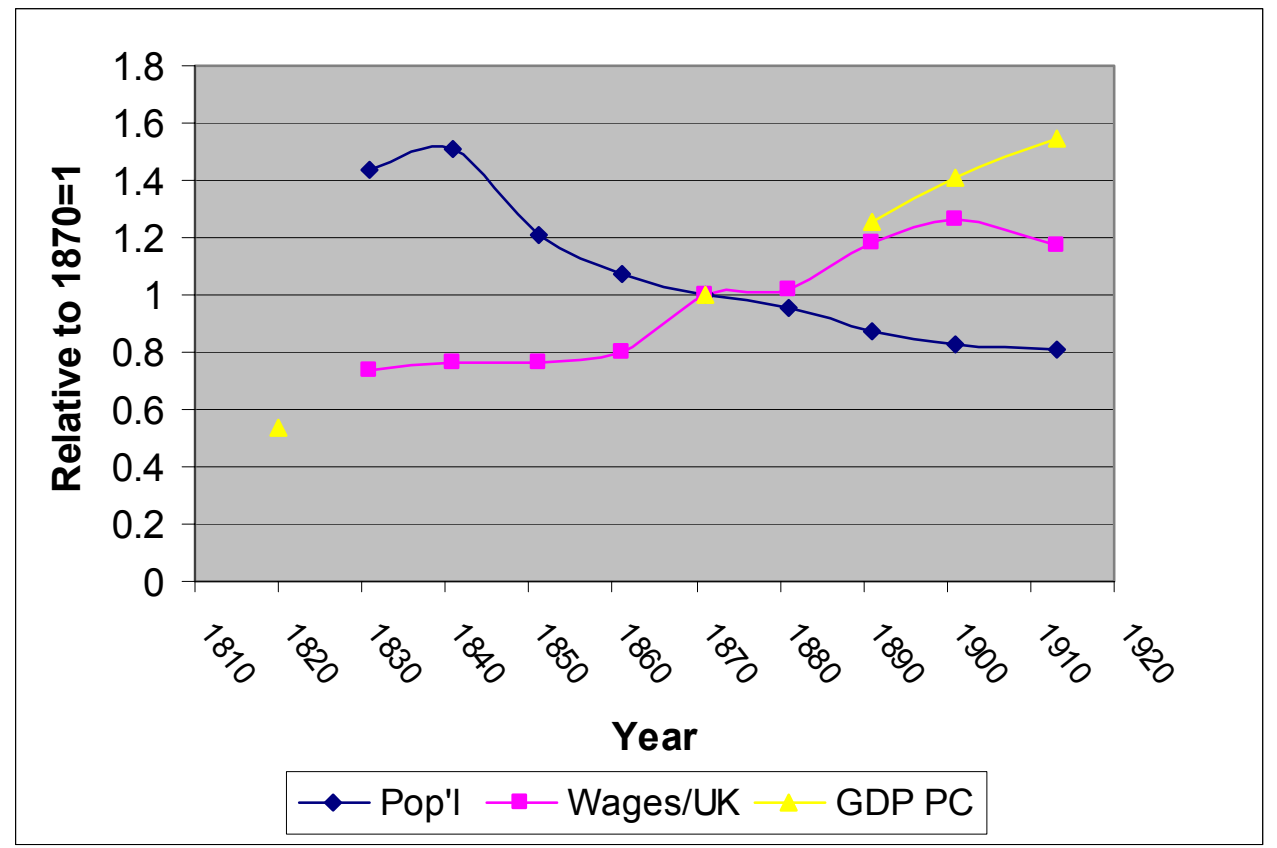

Source: Maddison (2002) for population and GDP PC. Williamson and O'Rouke (1997) for real wages.

Ireland's experience with adjustment to negative shocks during an era of labor mobility can be compared to any number of countries in more recent times-I'll use Bolivia first since it has comparable wage data over time ${ }^{19}$. Sometime in the late 1970 s

\footnotetext{
${ }^{19}$ Although not quite, as I had to extrapolate the wage data in the mid 1980s since the raw wage data were anomalous, likely due to difficulties in exchange rate comparisons at official exchange rates during rapid inflation.

Draft: Comments Welcome 
Bolivia's economic growth slowed, stopped, and reversed due in part to negative shocks to Bolivia's extractive industries. How did Bolivians adjust to these shocks? Population today is almost 90 percent higher than in 1972. In contrast, real industrial wages (at official exchange rates) have fallen from a peak of 14 percent of US levels to only 8 percent of US levels. Real GDP per worker in 1992 was only 62 percent of its peak.

Figure 10: During the period of accommodating negative shocks Bolivia displays exactly the opposite dynamics-population has increased by over 50 percent while real wages and GDP per person have fallen

(Index of population, real industrial wages relative to the USA, and GDP per capita, 1972=1)

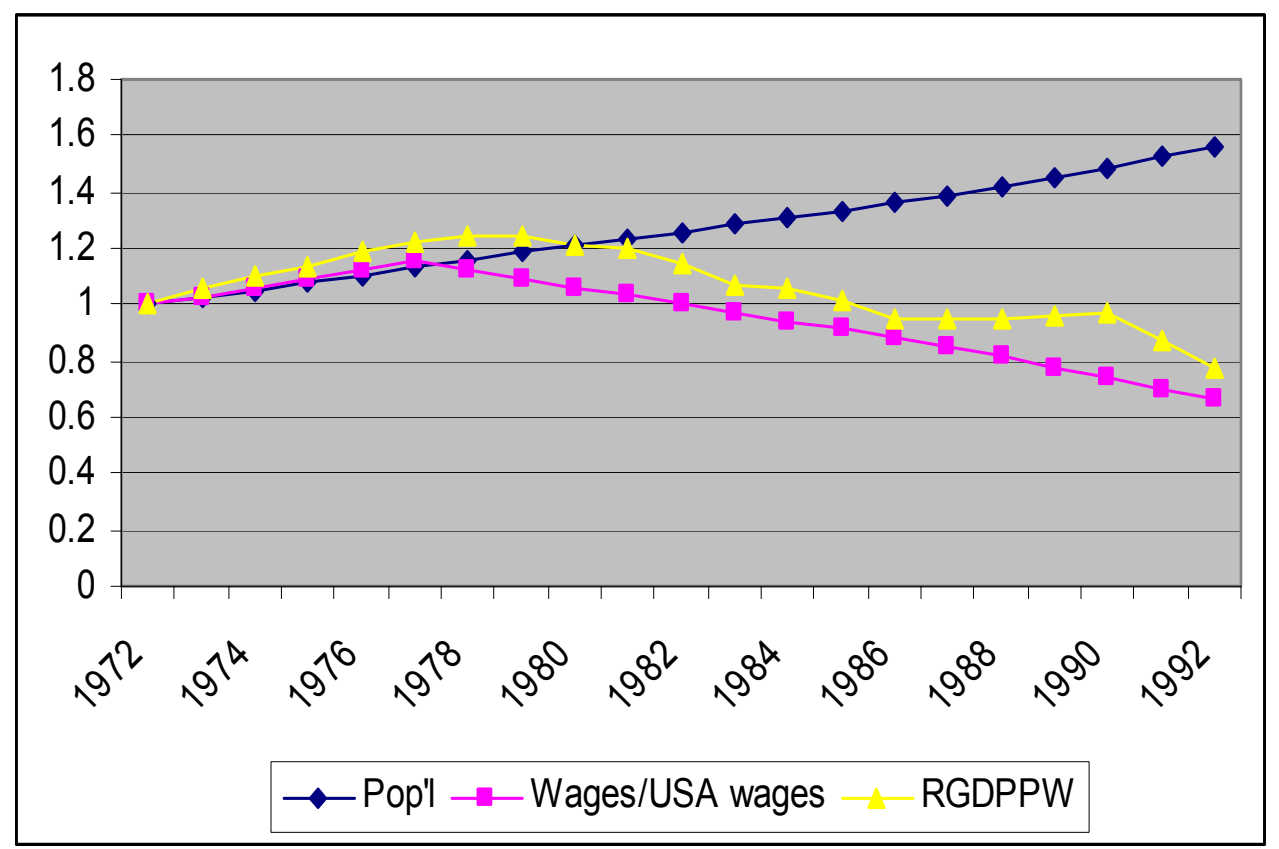

Source: Penn World Tables 6.0 for output and population. Arcetona and Rama (2003) for industrial wages.

Comparing Ireland to Bolivia highlights the obvious: that nearly all developing countries with negative shocks have seen their populations continue to expand rapidly while when there was freer labor mobility in the international system labor movements accommodated negative shocks. 


\section{Are there currently ghost countries?}

One should rightly hesitate to declare that any particular territory is simply incapable of supporting its current population at acceptable standards of living. But, on the other hand simply maintaining a fiction because it is politically convenient for the industrialized countries is no better. I define potential "ghost" countries (which are all, given the lack of population mobility, zombies) as countries where (a) GDP per capita has fallen by more than 20 percent from peak to trough (where for data purposes the peak must come before 1990 so recent ghosts are ruled out), (b) GDP per capita today remains less than 90 percent of peak GDP. This produces a list of 33 countries.

Of this list I have no way of showing which are "geographic" ghosts and which are not. In particular, I have no way of knowing which of these "policy and institutional" ghosts and which are "geographic" ghosts. That is, it could be that anticipated output fell because of disastrously bad politics or policies, which, if reversed, would cause the area to be enormously attractive - think of the boom Cuba is going to have when Castro is gone for instance. To document which are geographic ghosts I would have to specify and parameterize some particular model of location which would require grappling with the thorny issues of increasing returns to scale, etc. Instead, I will do two calculations which are hypothetical and simply illustrate the consequences of the possibility these countries are ghosts.

First, because output per person has fallen in all of these countries (by definition) I ask the question: "if desired population has received as large a negative shock relative to its peak in this country as it has in the counter-factual [see three options below] then what is the ratio of the post shock population to the current population?" The three count- 
factual scenarios are- "What if population in country Y has fallen relative to its population at peak GDP per capita has fallen in country Y by as much as actual population...

- Fell peak to trough fall in Ireland in the $19^{\text {th }}$ century (53 percent)?

- Fell between 1930 and 1990 in three regions of the USA (Deep South, Great Plains North, Pennsylvania Coal)—(28 percent)?

- Rose only as fast as the bottom $10^{\text {th }}$ percentile of population growth in regions of the eight OECD countries in table 1 (.01 percent per annum).

This is obviously not "proof" about the changes in desired populations of the countries - but just a matter of exploring the implications of plausible counter-factual scenarios. In all of these regions GDP per capita rose substantially while populations fell. In the countries GDP per capita has fallen while populations rose. It is at least plausible these simply represent different adjustments to similar sized shocks to geographic specific maximal incomes - pushing the adjustment either into wages and capital stocks or into population movement.

Second, I ask the question: if the elasticity of GDP per person with respect to population is negative 0.4 by how much would population have to fall in order to:

- Restore previous peak GDP per capita, or

- Move GDP per capita to the level it would be had it grown at 2 ppa since the peak (roughly the world average growth rate and hence just avoids divergence)

Table 4a begins with potentially "hard core" ghosts for three reasons. First, the decline is more likely geographic than policy or institutional. While none of these 
countries has terrific policies or institutions - they are not the Zaire's of the world that are "institutional ghosts." Second, all of these countries are landlocked, which makes the substitution into other industries more difficult. Third, they all have "small" populations (less than 20 million) which suggests that, in a locational equilibrium with population mobility there might not be sufficient population for even one "city" in which case the declines in desired population might be even more dramatic than those in the table.

Since I began with Zambia, let me use Zambia to illustrate the very simple way the five scenarios work and the results. Zambia's GDP per capita peaked in 1964 when its population was 3.5 million. Today, GDP per capita is only 59 percent of its peak and population is 10.0 million. If Zambia's population had fallen from its 1964 level by as much as Ireland's actual population (48 percent) then population today would be only 1.86 million -18 percent of its current level. If Zambia's population had fallen from its 1964 level by as much as population has fallen in three of the ghost regions in the USA (28 percent) then its population would only be 2.52 million -25 percent of its current level. If Zambia's population had grown at the .01 percent of the $10^{\text {th }}$ percentile in population growth regions of eight OECD countries its population would be about what it is today, 3.52 million — but that is only 35 percent of its current level.

The two output scenarios provide similarly striking ratios. Under the simple assumptions made population and output per person, population would have to fall to 14 percent of its current level to raise GDP per person to the level of a non-divergent trend. This is consistent with a negative shock roughly the magnitude of Ireland's. To raise output per person just to its previous peak, population would have to fall to 36 percent of their current levels. 
Table 4a: How large is the ghosthood? (potential hard core ghosts)

Ratios of the population would be to the current actual population if...

...the shock was as large as the realized population changes in the following three cases:

...the labor force fell to restore GDP per capita to $\mathrm{X}$ assuming an elasticity of output per person to population of -.4

\begin{tabular}{|l|l|l|l|l|l|l|l|l|}
\hline Country & $\begin{array}{l}\text { Year of } \\
\text { peak } \\
\text { GDP } \\
\text { per } \\
\text { capita }\end{array}$ & $\begin{array}{l}\text { Ratio } \\
\text { GDPpc }_{\text {2000 }} / \\
\text { GDPpc }_{\text {peak }}\end{array}$ & $\begin{array}{l}\text { Current } \\
\text { population }\end{array}$ & $\begin{array}{l}\text { Ireland } \\
\mathbf{4 8 \%} \text { fall } \\
\text { from } \\
\mathbf{1 8 4 1} \text { to } \\
\mathbf{1 9 2 6}\end{array}$ & $\begin{array}{l}\text { USA } \\
\text { ghost } \\
\text { regions } \\
\mathbf{2 8 \%} \\
\text { fall from } \\
\mathbf{1 9 3 0 -} \\
\mathbf{1 9 9 0}\end{array}$ & $\begin{array}{l}\text { OECD } \\
\text { lagging } \\
\text { regions } \\
\text { average } \\
\text { of pof } \\
\text { population } \\
\text { growth } \\
\mathbf{( 0 . 0 1 \%} \\
\text { per } \\
\text { annum } \\
\text { growth) }\end{array}$ & $\begin{array}{l}\text { Previous } \\
\text { peak } \\
\text { GDPpc } \\
\mathbf{0 . 4}\end{array}$ & $\begin{array}{l}\text { GDPpc } \\
\text { implying 2 } \\
\text { ppa growth } \\
\text { since peak } \\
\text { (No } \\
\text { Divergence) } \\
\mathbf{0 . 4}\end{array}$ \\
\hline Zambia & 1964 & 0.59 & 10089 & $18 \%$ & $25 \%$ & $35 \%$ & $36 \%$ & $14 \%$ \\
\hline CAF & 1970 & 0.44 & 3603 & $27 \%$ & $37 \%$ & $51 \%$ & $24 \%$ & $11 \%$ \\
\hline Niger & 1963 & 0.50 & 10832 & $17 \%$ & $23 \%$ & $32 \%$ & $29 \%$ & $11 \%$ \\
\hline Chad & 1979 & 0.50 & 7694 & $30 \%$ & $41 \%$ & $57 \%$ & $29 \%$ & $17 \%$ \\
\hline Rwanda & 1981 & 0.75 & 8508 & $33 \%$ & $45 \%$ & $63 \%$ & $55 \%$ & $30 \%$ \\
\hline Bolivia & 1978 & 0.87 & 8329 & $33 \%$ & $44 \%$ & $62 \%$ & $72 \%$ & $34 \%$ \\
\hline Romania & 1986 & 0.74 & 22435 & $54 \%$ & $74 \%$ & $103 \%$ & $54 \%$ & $34 \%$ \\
\hline
\end{tabular}

Source: Author's calculations.

I am aware of how striking these numbers are. It is not implausible that the desired population of the Sahel (Niger, Chad) has fallen by as much as the desired population of the Great Plains North counties of the United States. In fact, there are many reasons to expect the changes in desired population are probably larger in the Sahel. If this is so then if population mobility were not constrained 3 out of every 4 people would leave Niger and this might only be enough to restore output to its level of 1963. With the simple assumed elasticities Chad just to its previous peak (1979) GDP per capita would require 7 of every 10 people leave Chad. 
Table $4 \mathrm{~b}$ contains a variety of other countries. Some are possible "institutional" ghosts-which in some cases are countries in which output per person fell, at least initially, because of wide-spread armed conflict (Mozambique, Nicaragua, El Salvador). To some extent these are the most hopeful ghosts because it is possible that desired population can recover very quickly. In others the fall in output is strongly associated with deterioration in the terms of trade, particularly for oil-(e.g. Nigeria, Venezuela). Jamaica is an interesting case - precisely because out-migration has already played such a large role in population dynamics. By the "OECD laggard" scenario Jamaica's current population is 73 percent — which is because Jamaica's population has in fact grown so slowly, at only 1.2 ppa versus the 2.2 ppa of the rate of natural increase. It is already the case that there are nearly as many people that are "Jamaican" living outside of the national territory of Jamaica as within it. 
Table 4b: How large is the ghosthood?

Ratios of the population would be to the current actual population if...

...the shock was as large as the realized population changes in the following three cases:

...the shock was as large as the realized population changes in the following three cases:

\begin{tabular}{|c|c|c|c|c|c|c|c|c|}
\hline Country & $\begin{array}{l}\text { Year of } \\
\text { peak } \\
\text { GDP } \\
\text { per } \\
\text { capita }\end{array}$ & $\begin{array}{l}\text { Ratio } \\
\text { GDPpc }_{2000} / \\
\text { GDPpc } \\
\text { GDP }\end{array}$ & $\begin{array}{l}\text { Current } \\
\text { population }\end{array}$ & $\begin{array}{l}\text { Ireland } \\
48 \% \text { fall } \\
\text { from } 1841 \\
\text { to } 1926\end{array}$ & $\begin{array}{l}\text { USA } \\
\text { ghost } \\
\text { regions } \\
28 \% \\
\text { fall from } \\
1930- \\
1990\end{array}$ & $\begin{array}{l}\text { OECD } \\
\text { lagging } \\
\text { regions } \\
\text { (average } \\
\text { of } p_{10} \text { of } \\
\text { population } \\
\text { growth } \\
(0.01 \% \\
\text { per } \\
\text { annum } \\
\text { growth) }\end{array}$ & $\begin{array}{l}\text { Previous } \\
\text { peak } \\
\text { GDPpc }\end{array}$ & $\begin{array}{l}\text { GDPpc } \\
\text { implying } 2 \\
\text { ppa growth } \\
\text { since peak } \\
\text { (No } \\
\text { Divergence) }\end{array}$ \\
\hline BDI & 1977 & 0.60 & 6807 & $30 \%$ & $40 \%$ & $56 \%$ & $37 \%$ & $20 \%$ \\
\hline TGO & 1969 & 0.61 & 4527 & $23 \%$ & $31 \%$ & $43 \%$ & $39 \%$ & $17 \%$ \\
\hline MDG & 1971 & 0.65 & 15523 & $24 \%$ & $33 \%$ & $45 \%$ & $43 \%$ & $19 \%$ \\
\hline NAM & 1979 & 0.70 & 1718 & $31 \%$ & $42 \%$ & $58 \%$ & $48 \%$ & $25 \%$ \\
\hline $\mathrm{COG}$ & 1984 & 0.80 & 3018 & $33 \%$ & $45 \%$ & $62 \%$ & $61 \%$ & $36 \%$ \\
\hline JAM & 1972 & 0.80 & 2633 & $39 \%$ & $53 \%$ & $73 \%$ & $62 \%$ & $26 \%$ \\
\hline GAB & 1978 & 0.81 & 1230 & $28 \%$ & $38 \%$ & $53 \%$ & $63 \%$ & $30 \%$ \\
\hline GMB & 1984 & 0.85 & 1303 & $29 \%$ & $40 \%$ & $55 \%$ & $69 \%$ & $39 \%$ \\
\hline JOR & 1986 & 0.85 & 4887 & $30 \%$ & $40 \%$ & $56 \%$ & $69 \%$ & $42 \%$ \\
\hline SEN & 1960 & 0.89 & 9530 & $18 \%$ & $24 \%$ & $34 \%$ & $77 \%$ & $21 \%$ \\
\hline $\mathrm{COM}$ & 1968 & 0.59 & 558 & $24 \%$ & $33 \%$ & $45 \%$ & $37 \%$ & $16 \%$ \\
\hline CIV & 1979 & 0.61 & 16013 & $26 \%$ & $35 \%$ & $49 \%$ & $39 \%$ & $21 \%$ \\
\hline CMR & 1986 & 0.67 & 14876 & $37 \%$ & $50 \%$ & $69 \%$ & $45 \%$ & $29 \%$ \\
\hline GNQ & 1974 & 0.79 & 457 & $28 \%$ & $38 \%$ & $52 \%$ & $60 \%$ & $26 \%$ \\
\hline GHA & 1972 & 0.87 & 19306 & $25 \%$ & $34 \%$ & $47 \%$ & $73 \%$ & $29 \%$ \\
\hline AGO & 1973 & 0.39 & 11317 & $27 \%$ & $37 \%$ & $52 \%$ & $20 \%$ & $11 \%$ \\
\hline $\mathrm{MOZ}$ & 1973 & 0.49 & 17691 & $30 \%$ & $41 \%$ & $57 \%$ & $28 \%$ & $14 \%$ \\
\hline MRT & 1976 & 0.60 & 2576 & $29 \%$ & $39 \%$ & $55 \%$ & $38 \%$ & $19 \%$ \\
\hline SLE & 1970 & 0.62 & 4630 & $30 \%$ & $41 \%$ & $58 \%$ & $39 \%$ & $17 \%$ \\
\hline SLV & 1978 & 0.90 & 6276 & $37 \%$ & $51 \%$ & $71 \%$ & $78 \%$ & $36 \%$ \\
\hline NIC & 1977 & 0.40 & 5071 & $28 \%$ & $38 \%$ & $53 \%$ & $21 \%$ & $12 \%$ \\
\hline VEN & 1970 & 0.61 & 24170 & $24 \%$ & $32 \%$ & $44 \%$ & $38 \%$ & $17 \%$ \\
\hline TZA & 1987 & 0.64 & 33696 & $36 \%$ & $50 \%$ & $69 \%$ & $41 \%$ & $28 \%$ \\
\hline PER & 1975 & 0.86 & 25661 & $31 \%$ & $43 \%$ & $59 \%$ & $71 \%$ & $31 \%$ \\
\hline ZAR & 1970 & 0.27 & 46754 & $23 \%$ & $31 \%$ & $43 \%$ & $13 \%$ & $6 \%$ \\
\hline NGA & 1974 & 0.53 & 126910 & $25 \%$ & $34 \%$ & $47 \%$ & $31 \%$ & $16 \%$ \\
\hline
\end{tabular}

Source: Author's calculations. 


\section{Conclusion}

It would be convenient in many ways if the proposition that every country can achieve high and rising standards of living for their populations were factually true. One reason why it would be convenient is that the present international system and international organizations are, more or less, founded on this premise. Hence this paper is a clear demonstration of an inconvenient fact and its implications. The inconvenient fact is that, at least in the three cases examined-regions within countries, counties within the USA, Ireland in the "Atlantic economy" (O'Rourke and Williamson 2002) when people are allowed to move they do move, in massive numbers. This strongly suggests that even with fully integrated economies - far more integrated that "globalization" can likely achieve - there are large changes in the "desired" populations of areas over time ${ }^{20}$. These changes in desired population can be accommodated with population movements and the equalization (or at least non-divergence) of incomes. These movements create rising populations in cities and in booming areas and relative and absolute population declines in other areas. The extreme is the creation of regions that are a "ghost" of their former self.

Without population mobility geographic specific shocks create a different dynamic - one of falling wages and outputs. If labor supply cannot be elastic then prices must adjust, not quantities. The consequence is that it is plausible that even in a fully "globalized" world and even with the best possible "policies and institutions" some

\footnotetext{
${ }^{20}$ The apparent counter-example, which I do not examine, is the mobility of labor within the existing EU in which the conventional wisdom is that population mobility is "lower than expected." My suspicion is that since this made labor mobile where it was already mobile within large countries, and for which there were not large potential income gaps, and for economies in which geographic factors are small and agglomeration economies are sufficient in each (there are no EU "ghost countries) that the small labor mobility is not so unexpected.
} 
countries will not succeed - they are potentially ghost countries but are forced by restrictions on population mobility into an existence as zombies.

Why do I wish to stress this inconvenient fact and the uncomfortable idea that Zambia might be a zombie? Precisely because all current policy discussions focus only on Zambia - the nation-state--and not on Zambians the people. International organizations and international negotiations and international forums tend to be exactly that -international where the actors and agents all represent nation-states and their interests. There are structured organizations and institutions for bringing about reductions in the barriers to the movement of goods, for the movement of finance. There are organizations to bring about national development. But almost certainly the easiest way to improve the living standards of a Zambian is not to improve living standards in Zambia but to allow the person the choice to move out of Zambia. Perhaps bringing this opportunity about needs to come more strongly on the world's policy agenda.

Finally, in some discussions of this paper people have suggested that it was "insensitive" to suggest even the possibility that all existing national boundaries do not encompass a viable economy capable of sustaining their current population at anything like a decent standard of living. But this "political correctness" critique of doubting national viability is misguided - as it mistakes "nations" for something real. Who created the borders? Who created the "nations"? I would argue in fact that this view has it exactly backwards and that to insist on the interests of nation-states to control their borders over all other considerations - including the well-being of human beings, who through no action or fault of their own are trapped in economically non-viable regionsis not a normatively attractive view. 


\section{References}

Acemoglu, Daron: Simon Johnson, and James Robinson (2001), "The Colonial Origins of Comparative Development: An Empirical Investigation". American Economic Review, December:1369-140

Auty, Richard M. (1998). "Resource Abundance and Economic Development". World Institute for Development Economics Research. WIDER Studies in Development Economics. Oxford University Press. July 2001.

Barro, Robert and Xavier Sala-i-Martin (1997) "Technological Diffusion, Convergence, and Growth". Journal of Economic Growth.

Ben-David, Dan 1994 "Convergence Clubs and Diverging Economies". Centre for Economic Policy Research. CEPR Discussion Paper 922.

Blanchard, Olivier and Lawrence Katz, 1992, "Regional Evolutions" Brookings Papers on Economic Activity, 1992:1.

Bourguignon, F., and C. Morrison, (2002). "Inequality among World Citizens: 1820-1992." American Economic Review, September:727-44

Braun, Matias, Ricardo Hausmann, and Lant Pritchett. (May 2002). "The Proliferation of Sovereigns: Are there Lessons for Integration." Working Paper.

Easterly, William and Ross Levine 2002 "It's Not Factor Accumulation: Stylized Facts and Growth Models" forthcoming: World Bank Economic Review, 15, 2001, pp. 177-219.

Fujita, M.; Paul Krugman and Anthony Venables (1999) "The Spatial Economy". Cambridge, MA. The MIT Press.

Glaeser, Edward and Joseph Gyourko (2003), Urban Decline and Durable Housing.

Glaeser, Edward and Janet Kohlhase (2003) "Cities, Regions and the Decline of Transport Costs". NBER Working Paper No. w9886

Hatton, Timothy and Jeffrey Williamson (1998) "The Age of Mass Migration - Causes and Economic Impact". Oxford University Press.

Helpman, Elhanan and Paul Krugman (1987) "Market Structure and Foreign Trade: Increasing Returns, Imperfect Competition, and the International Economy". Cambridge, MA: The MIT Press.

Isham, Jonathan; Lant Pritchett and Michael Woolcock (2003)" The Varieties of the Resource Experience: How Natural Resource Export Structures Affect the Political Economy of Economic Growth"

Jones, Charles (2003) "Growth, Capital Shares, and a New Perspective on Production Functions". U.C. Berkeley. Mimeo.

King, Robert and Ross Levine (1992) "Financial Indicators and the Growth in a Cross Section of Countries". World Bank Working Papers 819.

King, Robert and Ross Levine (1993) "Finance and Growth: Schumpeter might be right". Quarterly Journal of Economics, No. 108, pp. 717-737. MIT Press.

King, Robert and Ross Levine (1993) "Finance, Entrepreneurship, And Growth - Theory And Evidence". Journal of Monetary Economics 32 (3): 513-542 
King, Robert and Ross Levine (1993) "Finance, Entrepreneurship, and Growth: Theory and Evidence". Journal of Monetary Economics, 32(3), 513-542.

King, Robert and Ross Levine (1994) "Capital Fundamentalism, Economic Development, and Economic Growth". Carnegie-Rochester Public Policy Conference Series, Vol. 40, 994, 259-292.

Kremer, Michael (1993) "Population Growth and Technological Change: 1,000,000 B.C. to 1990," Quarterly Journal of Economics. August, 1993, pp. 681-716.

Krugman, Paul (1991) "Increasing Returns and Economic Geography," Journal of Political Economy.

Krugman, Paul (1991) "Geography and Trade”. MIT Press.

Krugman, Paul (1998) "The Role of Geography in Development" Paper prepared for the Annual World Bank Conference on Development Economics, Washington, D.C.

Krugman and Anthony Venables (1995) "The Seamless World: A Spatial Model of International Specialization," NBER Working Papers 5220.

Lucas, Robert (1988)"On the Mechanics of Economic Development," Journal of Monetary Economics, 22(1), pp. 3-42.

Lucas, Robert (1990) Why doesn't capital flow from rich to poor countries?" American Economic Review 80, no. 2: 92-96.

Mankiw, Gregory; David Romer and David Weil (1992) "A Contribution to the Empirics of Economic Growth," The Quarterly Journal of Economics, Vol. 107 (2) pp. 407-37.

Neary J. and K. Roberts (1980) "The theory of household behaviour under rationing", European Economic Review, 13, 25-42.

O'Rourke, Kevin and Jeffrey Williamson (2002) "Globalization and History: The Evolution of a Nineteenth-century Atlantic Economy”. Cambridge, MA: MIT Press.

Pritchett, Lant (1997) "Divergence, Big Time”. Journal of Economic Perspectives, 11, 3-17.

Romer, Paul (1986) "Increasing Returns and Long Run Growth". Journal of Political Economy, 94, 1002-37.

Sachs, Jeffrey; Andrew Mellinger and John Gallup (1999) "Climate, Water Navigability, and Economic Development". CID Working Paper Number 24.

Sachs, Jeffrey and Andrew Warner (2001). "The Curse of Natural Resources". European Economic Review. Vol. 45.

Sala-i-Martin, Xavier (2002) "The Disturbing "Rise" of World Income Inequality". NBER Working Paper 8904.

Sokoloff, Kenneth and Stanley L Engerman (1994) "Factor Endowments: Institutions, and Differential Paths of Growth Among New World Economies: A View from Economic Historians of the United States". NBER Working Paper h0066.

Sokoloff, Kenneth and Stanley L Engerman (2002) "Factor Endowments, Inequality, and Paths of Development Among New World Economics". NBER Working Paper w9259.

Sokoloff, Kenneth and Stanley L Engerman (2003) "Institutional and Non-Institutional Explanations of Economic Differences”. NBER Working Paper w9989. 


\section{Appendix 1: Other regional pictures}
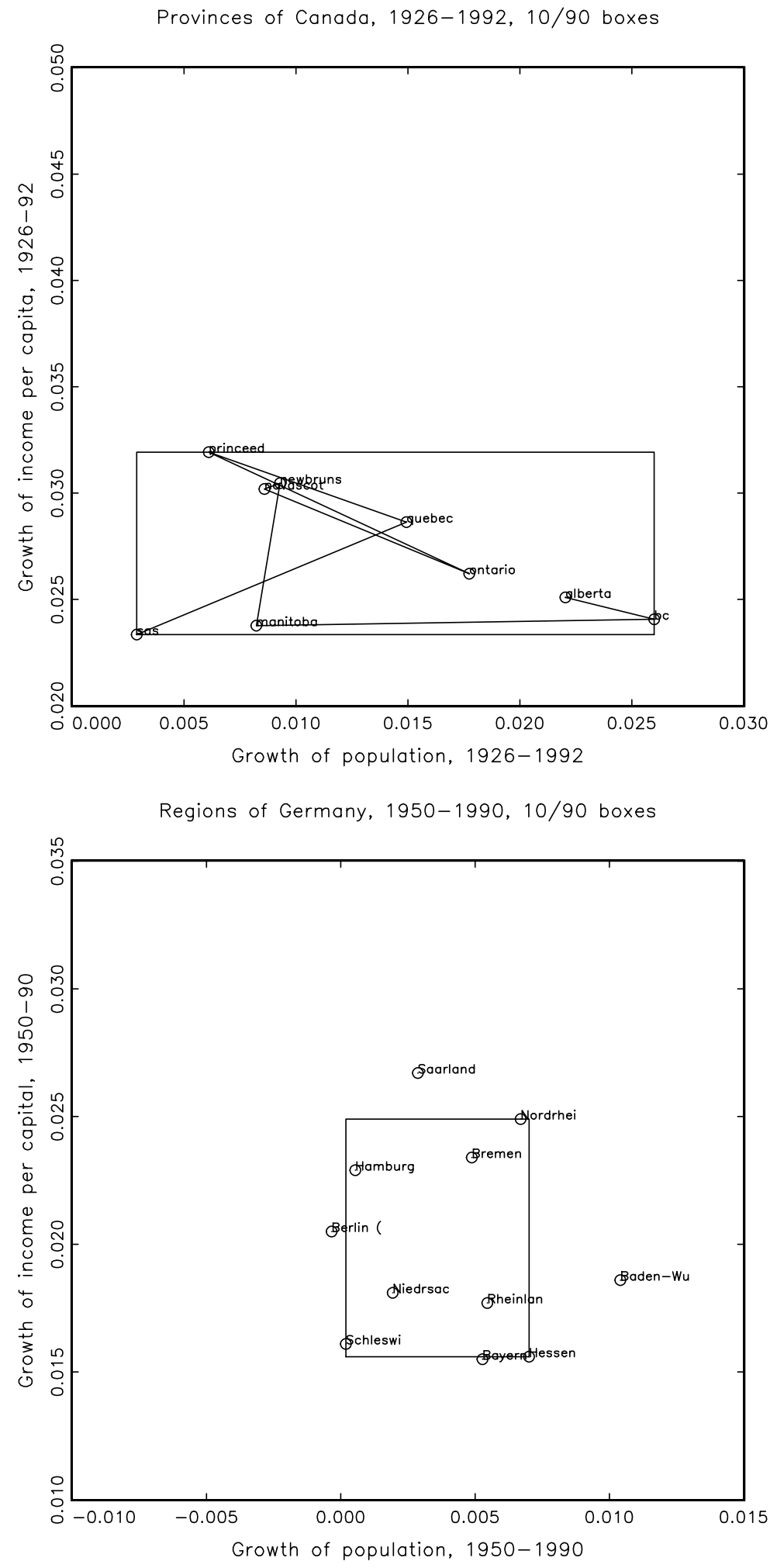
Regions of Spain, 1951-87,1951-1990, 10/90 boxes

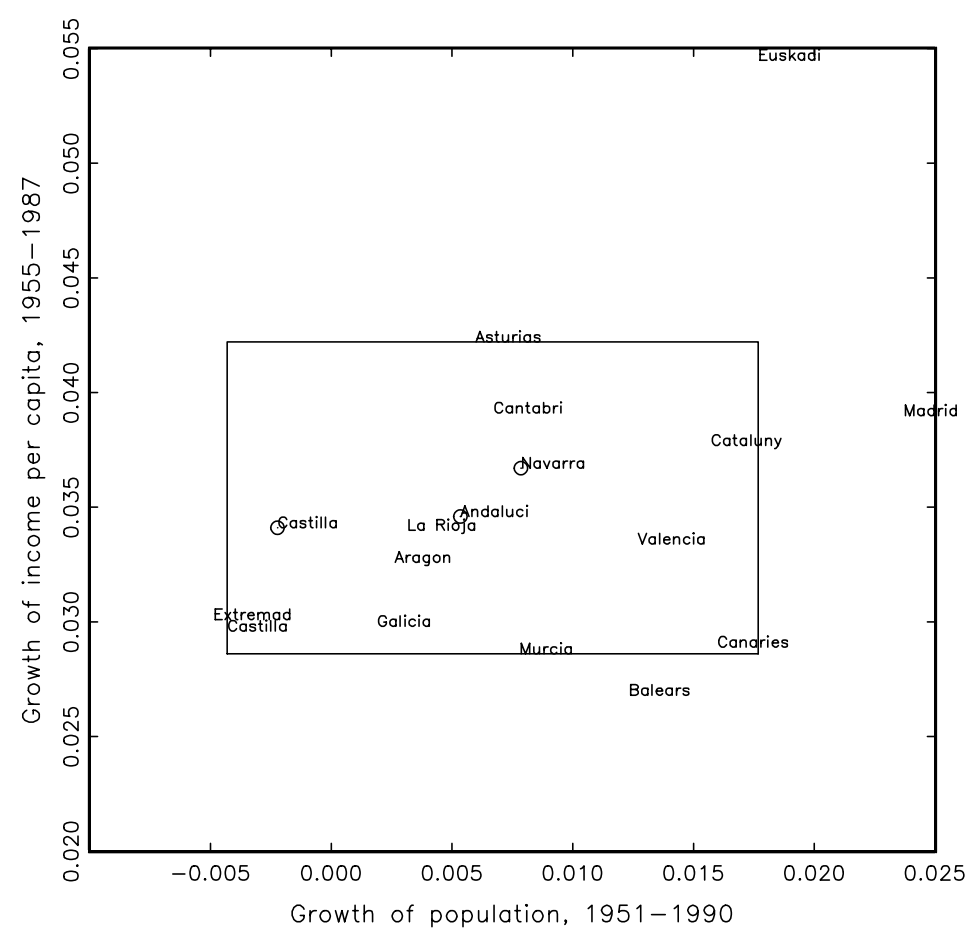

(Regions of United Kingdom, 1950-1990, 10/90 boxes

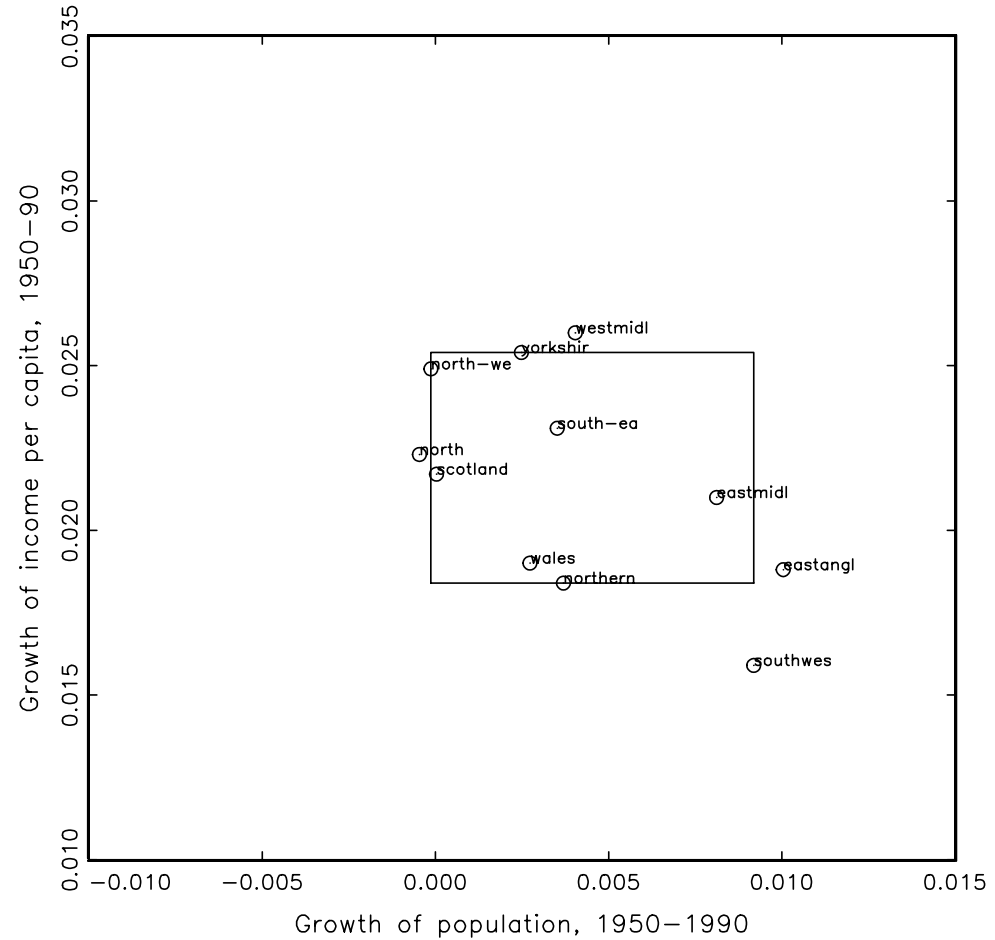


Regions of Italy, 1950-1990, 10/90 boxes

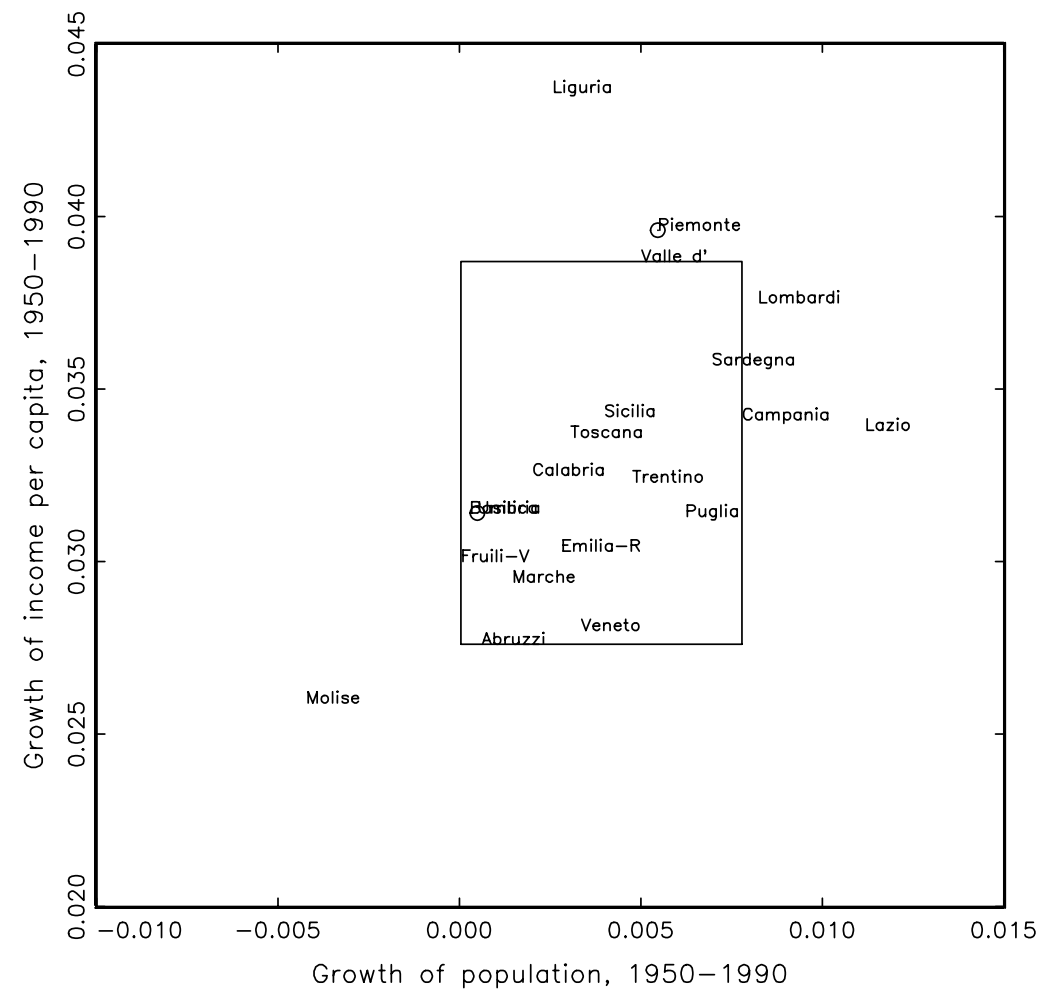

Regions of France, 1950-1990, 10/90 boxes

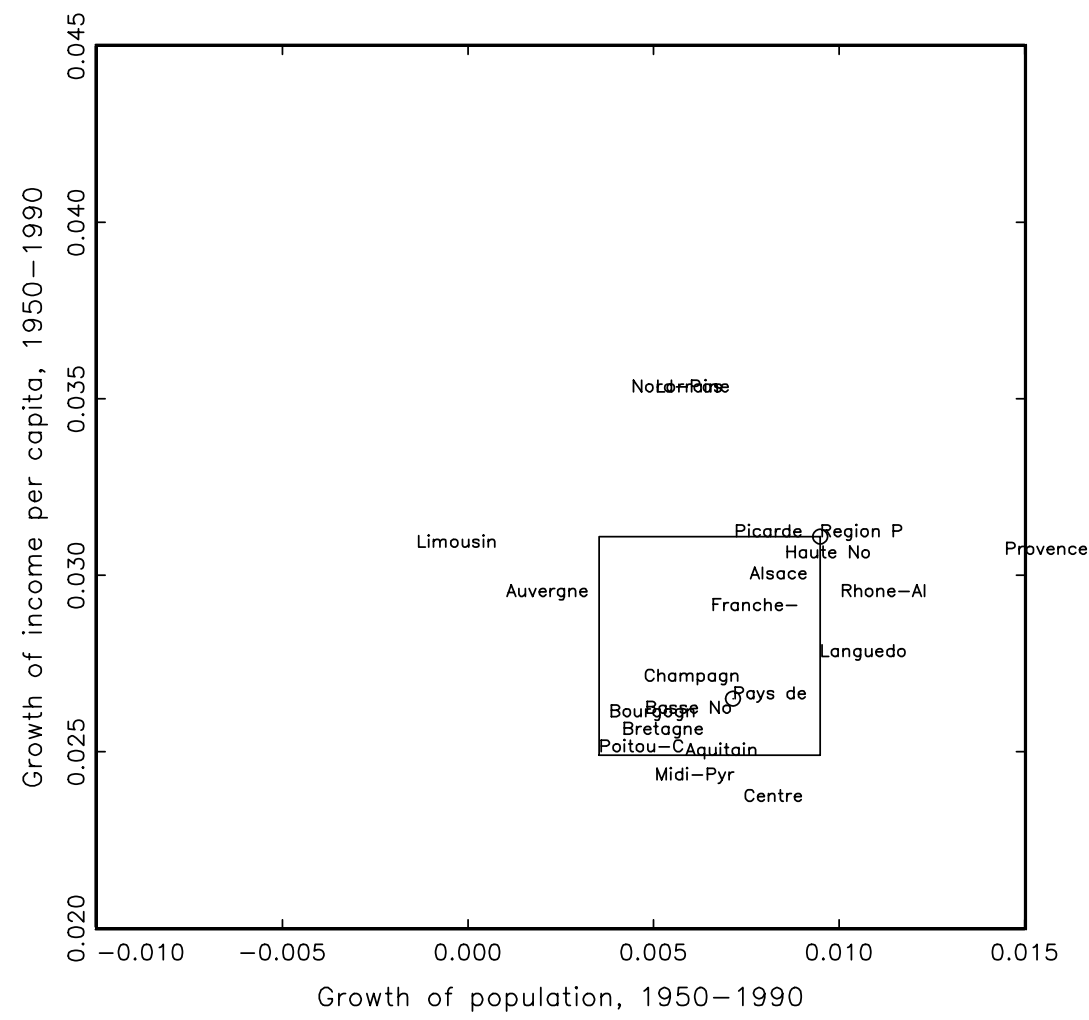


Table 5: Variance in growth of population and growth in GDP(or income) per capita across countries and regions.

\begin{tabular}{|c|c|c|c|c|c|c|c|c|}
\hline \multirow[t]{2}{*}{ Region } & \multirow[t]{2}{*}{$\begin{array}{l}\text { Unit } \\
\text { Number of } \\
\text { units }\end{array}$} & \multirow[t]{2}{*}{ Period } & \multicolumn{2}{|c|}{$\begin{array}{l}\text { Standard } \\
\text { deviations of } \\
\text { per annum } \\
\text { growth rates }\end{array}$} & \multirow[t]{2}{*}{$\begin{array}{l}\text { Ratio } \\
\frac{\sigma_{P}}{\sigma_{\frac{Y}{P}}}\end{array}$} & \multicolumn{2}{|c|}{ 10/90 difference } & \multirow{2}{*}{$\begin{array}{l}\text { Ratio } \\
10 / 90 \\
\text { diff. } \\
\text { growth } \\
\text { pop'l / } \\
\text { growth } \\
\text { Y/P }\end{array}$} \\
\hline & & & Pop'l & $\mathbf{Y} / \mathbf{P}$ & & Pop'l & $\mathbf{Y} / \mathbf{P}$ & \\
\hline \multicolumn{9}{|c|}{ Recent cross-national } \\
\hline $\begin{array}{l}\text { World } \\
\text { (pop'l-RNI) }\end{array}$ & 113 & \multirow{2}{*}{$\begin{array}{l}1950- \\
1990^{\mathrm{a}}\end{array}$} & .38 & 1.79 & .21 & 0.8 & 4.4 & 0.18 \\
\hline $\begin{array}{l}\text { World } \\
\text { (pop'l) }\end{array}$ & 122 & & .94 & 1.82 & .52 & .47 & 1.01 & .47 \\
\hline $\begin{array}{l}\text { Non-OECD } \\
\text { (pop'l-RNI) }\end{array}$ & 91 & \multirow{2}{*}{$\begin{array}{l}1950- \\
1990^{\mathrm{a}}\end{array}$} & .40 & 1.86 & .22 & 0.8 & 4.6 & 0.17 \\
\hline $\begin{array}{l}\text { Non-OECD } \\
\text { (pop'l) }\end{array}$ & 99 & & .78 & 1.92 & .41 & .34 & 1.22 & .28 \\
\hline \multicolumn{9}{|c|}{ Regions of non-European industrialized countries } \\
\hline USA & $\begin{array}{l}\text { States } \\
48\end{array}$ & $\begin{array}{c}1900- \\
1990\end{array}$ & .92 & .45 & 2.02 & 2 & 1.2 & 1.67 \\
\hline Canada & $\begin{array}{c}9 \\
\text { Provinces } \\
\end{array}$ & $\begin{array}{c}1926- \\
1992 \\
\end{array}$ & .78 & .33 & 2.37 & 2.3 & 0.9 & 2.56 \\
\hline Japan & $\begin{array}{c}47 \\
\text { Prefectures }\end{array}$ & $\begin{array}{l}1955- \\
1990\end{array}$ & .84 & .44 & 1.92 & 1.9 & 1 & 1.90 \\
\hline \multicolumn{9}{|c|}{ Regions of European countries } \\
\hline $\begin{array}{l}\text { United } \\
\text { Kingdom }\end{array}$ & 11 & $\begin{array}{l}1950- \\
1990\end{array}$ & .37 & .32 & 1.14 & 0.9 & 0.7 & 1.29 \\
\hline France & 21 & $\begin{array}{c}1950- \\
1990\end{array}$ & .34 & .33 & 1.02 & 0.5 & 0.6 & 0.83 \\
\hline Spain & 17 & $\begin{array}{l}1951- \\
1990^{\mathrm{b}}\end{array}$ & .80 & .67 & 1.20 & 2.2 & 1.3 & 1.69 \\
\hline Italy & 20 & $\begin{array}{c}1950- \\
90 \\
\end{array}$ & .35 & .44 & .80 & 0.8 & 1.1 & 0.73 \\
\hline Germany & 11 & $\begin{array}{c}1950- \\
90 \\
\end{array}$ & .34 & .39 & .82 & 0.7 & 0.9 & 0.78 \\
\hline
\end{tabular}

(a) Uses all available data to calculate growth rates, uses all countries with more than 20 years of data, (b) Income data for Spain is for 1955-87.

Source: Based largely on regional data from Barro and Sala-i-Martin 1997. 


\section{Center for Global Development Working Papers}

No. 1, January 2002

No. 2, January 2002

No. 3, February 2002

No. 4, March 2002

No. 5, April 2002

No. 6, May 2002

No. 7, May 2002

No. 8 , June 2002

No. 9, August 2002

No. 10, Sept. 2002

No. 11, October 2002

No. 12, October 2002

No. 13, October 2002

No. 14, October 2002

No. 15, October 2002

No. 16, October 2002
Inequality Does Cause Underdevelopment: New Evidence, William Easterly

HIV/AIDS and the Accumulation and Utilization of Human Capital in Africa, Amar Hamoudi and Nancy Birdsall

External Advisors and Privatization in Transition Economies, John Nellis

The Cartel of Good Intentions: Bureaucracy versus Markets in Foreign Aid, William Easterly

Intellectual Property and the Availability of Pharmaceuticals in Developing Countries, Jean O. Lanjouw

Winners and Losers: Assessing the distributional impacts of privatization, Nancy Birdsall and John Nellis

Commodity Dependence, Trade, and Growth: When 'Openness' is Not Enough, Nancy Birdsall and Amar Hamoudi.

Financial Crises and Poverty in Emerging Market Economies, William Cline

An Identity Crisis? Testing IMF Financial Programming, William Easterly

Solutions when the Solution is the Problem: Arraying the Disarray in Development, Lant Pritchett and Michael Woolcock

What did structural adjustment adjust? The association of policies and growth with repeated IMF and World Bank adjustment loans, William Easterly

Asymmetric Globalization: Global Markets Require Good Global Politics, Nancy Birdsall

Low Investment is not the Constraint on African Development, Shantayanan Devarajan, William Easterly, Howard Pack

An Index of Industrial Country Trade Policy toward Developing Countries, William R. Cline

Tropics, Germs, and Crops: How Endowments Influence Economic Development, William Easterly and Ross Levine

Do As I Say Not As I Do: A Critique Of G-7 Proposals On Reforming The MDBs, Devesh Kapur 
No. 17, October 2002

No. 18 , Nov. 2002

No. 19, Dec. 2002

No. 20, December 2002

No. 21, December 2002

No. 22, January 2003

No. 23, February 2003

No. 24, February 2003

No. 25, February 2003

No. 26, March 2003

No. 27, May 2003

No. 28, July 2003

No. 29, April 2003

No. 30, July 2003

No. 31, August 2003

No. 32, September 2003
Policy Selectivity Foregone: Debt and Donor Behavior in Africa, Nancy Birdsall, Stijn Claessens and Ishac Diwan

Private Sector Involvement in Financial Crisis Resolution: Definition, Measurement, and Implementation, William R. Cline

Do Rich Countries Invest Less in Poor Countries Than the Poor Countries Themselves?, Michael A. Clemens

World Bank capital neither complements nor substitutes for private capital, Michael A. Clemens

From Social Policy to an Open-Economy Social Contract in Latin America, Nancy Birdsall

Global Economic Governance and Representation of Developing Countries: Some Issues and the IDB Example, Nancy Birdsall

The Millennium Challenge Account: How much is too much, how long is long enough?, Michael A. Clemens and Steve Radelet

Bootstraps Not Band-Aids: Poverty, Equity and Social Policy in Latin America, Nancy Birdsall and Miguel Szekely

Privatization in Africa: What has happened? What is to be done?, John Nellis

New Data, New Doubts: Revisiting "Aid, Policies, and Growth", William Easterly, Ross Levine, David Roodman

National Policies and Economic Growth: A Reappraisal, William Easterly

Financing Pharmaceutical Innovation: How Much Should Poor Countries Contribute?, William Jack and Jean O. Lanjouw

Economic Policy and Wage Differentials in Latin America, Jere R. Behrman, Nancy Birdsall and Miguel Székely

The Surprise Party: An Analysis of US ODA Flows to Africa, Markus P. Goldstein and Todd J. Moss

Privatization in Latin America, John Nellis

The Anarchy of Numbers: Aid, Development, and Cross-country Empirics, David Roodman

No. 33, November 2003 Who is not Poor? Proposing A Higher International Standard for Poverty, Lant Pritchett

No. 34, December 2003 Once more into the breach: economic growth and integration, Andrew Warner

No. 35, January 2004 The Illusion of Sustainability, Michael Kremer and Edward Miguel Draft: Comments Welcome 58 